\title{
Detection from space of a reduction in anthropogenic emissions of nitrogen oxides during the Chinese economic downturn
}

\author{
J.-T. Lin $^{1}$ and M. B. McElroy ${ }^{2}$ \\ ${ }^{1}$ Laboratory for Climate and Ocean-Atmosphere Studies, Department of Atmospheric and Oceanic Sciences, School of \\ Physics, Peking University, Beijing 100871, China \\ ${ }^{2}$ School of Engineering and Applied Sciences, Harvard University, Cambridge, MA 02138, USA
}

Received: 16 November 2010 - Published in Atmos. Chem. Phys. Discuss.: 6 January 2011

Revised: 19 July 2011 - Accepted: 1 August 2011 - Published: 10 August 2011

\begin{abstract}
Rapid economic and industrial development in China and relatively weak emission controls have resulted in significant increases in emissions of nitrogen oxides $\left(\mathrm{NO}_{\mathrm{x}}\right)$ in recent years, with the exception of late 2008 to mid 2009 when the economic downturn led to emission reductions detectable from space. Here vertical column densities (VCDs) of tropospheric $\mathrm{NO}_{2}$ retrieved from satellite observations by SCIAMACHY, GOME-2 and OMI (both by KNMI and by NASA) are used to evaluate changes in emissions of $\mathrm{NO}_{\mathrm{x}}$ from October 2004 to February 2010 identifying impacts of the economic downturn. Data over polluted regions of Northern East China suggest an increase of 27-33\% in 12-month mean $\mathrm{VCD}$ of $\mathrm{NO}_{2}$ prior to the downturn, consistent with an increase of $49 \%$ in thermal power generation (TPG) reflecting the economic growth. More detailed analysis is used to quantify changes in emissions of $\mathrm{NO}_{\mathrm{x}}$ in January over the period 2005-2010 when the effect of the downturn was most evident. The GEOS-Chem model is employed to evaluate the effect of changes in chemistry and meteorology on VCD of $\mathrm{NO}_{2}$. This analysis indicates that emissions decreased by $20 \%$ from January 2008 to January 2009, close to the reduction of $18 \%$ in TPG that occurred over the same interval. A combination of three independent approaches indicates that the economic downturn was responsible for a reduction in emissions by $9-11 \%$ in January 2009 with an additional decrease of $10 \%$ attributed to the slow-down in industrial activity associated with the coincident celebration of the Chinese New Year; errors in the estimate are most likely less than $3.4 \%$.
\end{abstract}

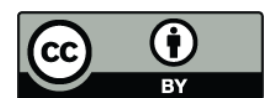

Correspondence to: J.-T. Lin (linjt@pku.edu.cn)

\section{Introduction}

Nitrogen oxides $\left(\mathrm{NO}_{\mathrm{x}} \equiv \mathrm{NO}+\mathrm{NO}_{2}\right)$ are an important constituent in the troposphere, affecting the formation of ozone and aerosols and acid deposition. They are emitted from anthropogenic combustion sources, biomass burning, soil and lightning. In the air, they are destroyed mainly through the formation of nitric acid under two major pathways, including reaction of $\mathrm{NO}_{2}$ with the hydroxyl radical $(\mathrm{OH})$ and heterogeneous reaction of nitrogen pentoxide $\left(\mathrm{N}_{2} \mathrm{O}_{5}\right)$ with liquid water on aerosol surfaces (Seinfeld and Pandis, 2006; Martin et al., 2003; Lamsal et al., 2010). They may also be converted to reservoirs like peroxyacetyl nitrate (PAN) and other organic nitrates (Seinfeld and Pandis, 2006). The partitioning of $\mathrm{NO}_{\mathrm{x}}$ into $\mathrm{NO}$ and $\mathrm{NO}_{2}$ is controlled by photolysis of $\mathrm{NO}_{2}$ and reactions of $\mathrm{NO}$ with ozone and the hydroperoxyl radical $\left(\mathrm{HO}_{2}\right)$ (Seinfeld and Pandis, 2006).

The Chinese economy grew rapidly over the past decades, resulting in significant increases in energy demand met primarily by increases in the use of coal and other fossil fuels (Chinese Statistical Yearbook 2009, 2009). This, together with relatively weak emission controls, has resulted in significant growth in emissions of $\mathrm{NO}_{\mathrm{x}}$ (Zhang et al., 2007, 2009a, b; Zhao et al., 2009; Lei et al., 2010; Lin et al., 2010a). Understanding the magnitude of emissions of $\mathrm{NO}_{\mathrm{x}}$ in China and its recent trend has been a challenge, however. The bottomup approach to estimating emissions of $\mathrm{NO}_{\mathrm{x}}$ relies on information on emission activities and emission factors (Streets et al., 2003; Zhang et al., 2007, 2009a; Zhao et al., 2009; Lei et al., 2010). Inadequacies and inaccuracies both in the statistics of emission activities and in measurements of emission factors have resulted in large uncertainties in bottom-up estimates (Streets et al., 2003; Zhang et al., 2007, 2009a; Zhao et al., 2010).

Published by Copernicus Publications on behalf of the European Geosciences Union. 
Vertical column densities (VCDs) of tropospheric nitrogen dioxide $\left(\mathrm{NO}_{2}\right)$ are retrieved from multiple satellite instruments, including GOME, SCIAMACHY, GOME-2, and OMI (Boersma et al., 2004; Richter et al., 2005; Boersma et al., 2007; Bucsela et al., 2008; Mijling et al., 2009). This information has been exploited to evaluate emissions of $\mathrm{NO}_{\mathrm{x}}$ in China from the top-down perspective as an alternative to the bottom-up approach (Martin et al., 2003; Jaeglé et al., 2005; Martin et al., 2006; Wang et al., 2007; Stavrakou et al., 2008; van der A et al., 2008; Lin and McElroy, 2010; Lin et al., 2010b). There are large uncertainties, however, associated with VCDs inferred for $\mathrm{NO}_{2}$ as a consequence of a variety of assumptions and errors introduced at different stages of the retrieval process (Boersma et al., 2004, 2007, 2009; Bucsela et al., 2008; Zhou et al., 2009; Hains et al., 2010; Lamsal et al., 2010; Lin et al., 2010b) (see Sect. 3). Lin et al. (2010b) proposed a methodology to reduce the effect of retrieval errors on the derivation of emissions by combining data from multiple satellite instruments. This procedure results in a more realistic estimate of emissions of $\mathrm{NO}_{\mathrm{x}}$ for different seasons (Lin and McElroy, 2010; Lin et al., 2010b). Questions remain however concerning the true magnitude of emissions and the effect of retrieval errors on top-down estimates.

Despite large uncertainties, retrieved VCDs of $\mathrm{NO}_{2}$ have been used extensively to evaluate variations in emissions of $\mathrm{NO}_{\mathrm{x}}$ in China that have occurred over the past 15 or so years. Combining retrievals from GOME and SCIAMACHY, Richter et al. (2005) showed that VCDs of $\mathrm{NO}_{2}$ increased by about $50 \%$ over industrial regions of China between 1996 and 2004. Their findings were supported by subsequent studies (van der A et al., 2006; He et al., 2007; Zhang et al., 2007; Stavrakou et al., 2008; van der A et al., 2008; Yue et al., 2009). Zhang et al. (2007) compared changes in emissions of $\mathrm{NO}_{\mathrm{x}}$ from 1995 to 2004 inferred from space with changes derived using the bottom-up methodology. Stavrakou et al. (2008) applied an assimilation approach to calculate changes in emissions of $\mathrm{NO}_{\mathrm{x}}$ in China corresponding to changes in $\mathrm{VCDs}$ of $\mathrm{NO}_{2}$ inferred from GOME and SCIAMACHY. They found an increase by about $66 \%$ from 1997 to 2006. Zhang et al. (2009b) employed changes in VCDs of $\mathrm{NO}_{2}$ retrieved from OMI to pinpoint the significant expansion of the thermal power sector in Inner Mongolia between 2005 and 2007. Mijling et al. (2009) found a notable decrease in VCDs of $\mathrm{NO}_{2}$ over North China based on retrievals from GOME-2 and OMI during the 2008 Beijing Olympics in response to restrictions imposed on traffic and mandated reductions in industrial activities.

The latest economic downturn of China that set in around late 2008 and persisted until late 2009 provides a good opportunity to evaluate the sensitivity of satellite retrievals to anthropogenic emissions of $\mathrm{NO}_{\mathrm{x}}$ associated with variations in economic activities (Lin et al., 2010a). The downturn resulted in a significant slowdown in energy demand that is clearly reflected in year-on-year (i.e., value compared to the

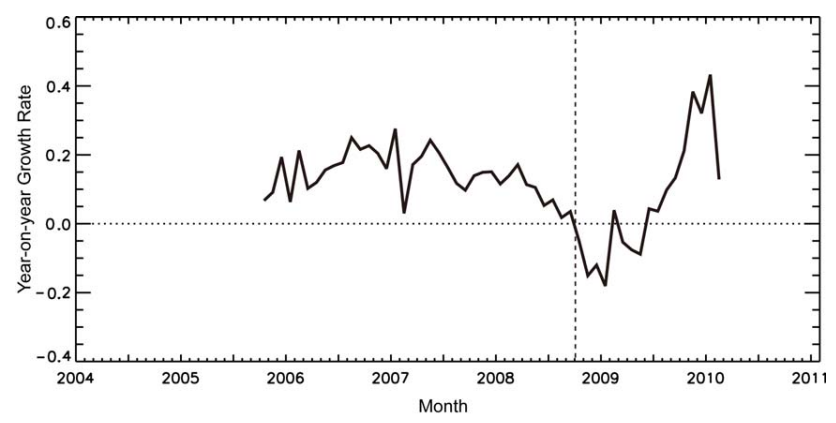

Fig. 1. Year-on-year growth rate in monthly thermal power generation in China. The value for a particular month is calculated as its percentage difference from the same month of the previous year. The vertical dashed line denotes the start of negative growth in thermal power generation.

same period in the previous year) changes of power generation (Fig. 1). Figure 1 shows that the rate of year-onyear growth in monthly thermal power generation (TPG), an indication of China's booming economy, started to decline in 2008 summer and became negative by October 2008. The growth rate stayed negative, with the lowest values over the 2008-2009 winter, until mid 2009 when TPG started to resume its growth. (The exception in February 2009 was a result of different timing of the Chinese New Year between 2008 and 2009; see below.) In this study, changes in tropospheric VCDs of $\mathrm{NO}_{2}$ retrieved from SCIAMACHY, GOME-2 and OMI are used to evaluate the impact of the economic downturn on emissions of $\mathrm{NO}_{\mathrm{x}}$. The inferred emission reductions are evaluated using the TPG data, and are contrasted to the general increase from October 2004 to February 2010.

Particular efforts are made to quantify changes in emissions of $\mathrm{NO}_{\mathrm{x}}$ in January from 2005 to 2010 based on retrieved VCDs of $\mathrm{NO}_{2}$, by identifying the effect of changes in chemistry and meteorology on VCDs of $\mathrm{NO}_{2}$ using simulations of the global chemical transport model (CTM) GEOSChem. Retrievals of $\mathrm{NO}_{2}$ in wintertime may be affected by larger solar zenith angle and snow/ice on the ground. Choosing such months, however, is based on considerations for a larger signal of the economic downturn, a better relation between anthropogenic sources of $\mathrm{NO}_{\mathrm{x}}$ and $\mathrm{VCDs}$ of $\mathrm{NO}_{2}$, as well as an interesting timing of the Chinese New Year affecting also economic activities. In the 2008-2009 winter, the economic downturn was at its most intense phase with largest reductions in TPG (Fig. 1), therefore the signal of changing economy can be better captured from space with smaller interference from retrieval errors and other contaminations. In winter, emissions of $\mathrm{NO}_{\mathrm{x}}$ from biomass burning, soil and lightning are very small in China (Jaeglé et al., 2005; Lin and McElroy, 2010), therefore a direct relation is easier to obtain between VCDs of $\mathrm{NO}_{2}$ and anthropogenic sources of $\mathrm{NO}_{\mathrm{x}}$. For other seasons, soil and lightning sources contribute to a 
(a) SCIAMACHY (2005-2010)

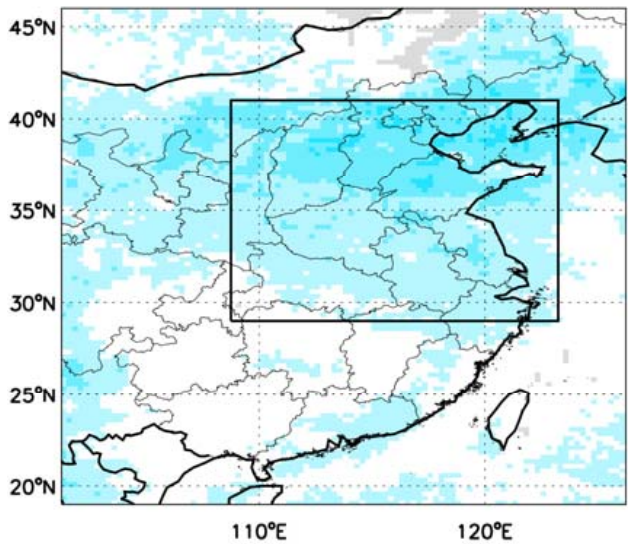

(c) OMI_KNMI (2005-2010)

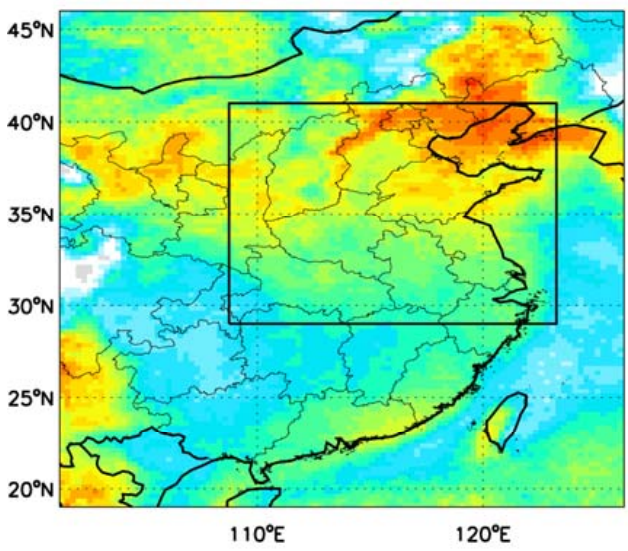

(b) GOME-2 (2008-2010)

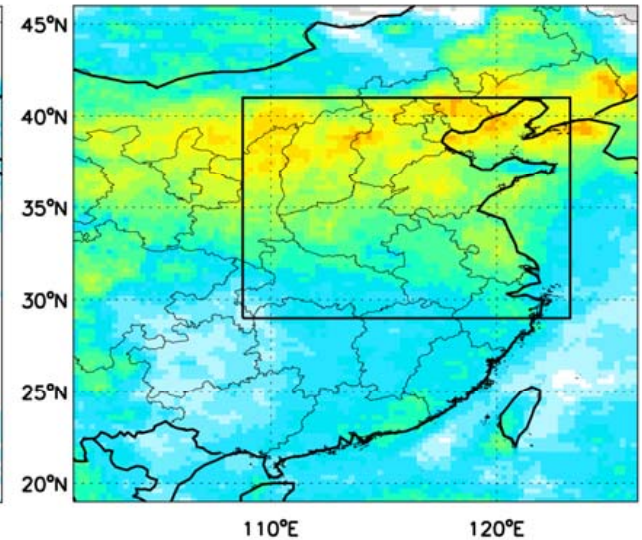

(d) OMI_NASA (2005-2010)

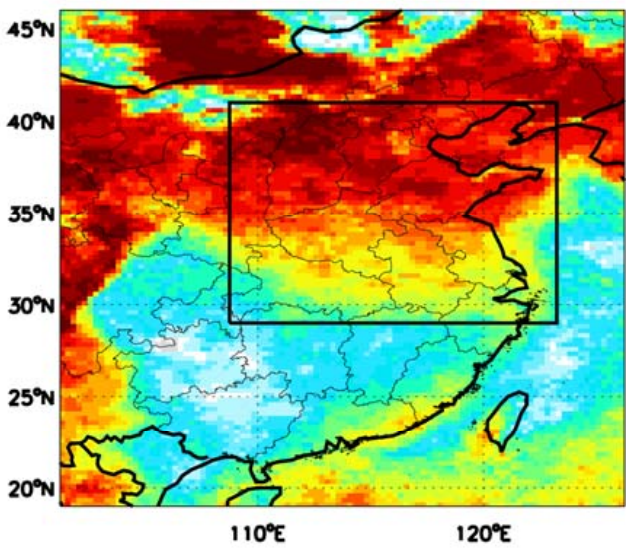

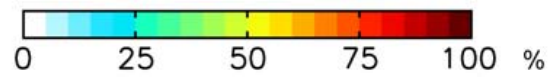

Fig. 2. The percentage of days in January with valid data averaged over 2005-2010 in the four retrieval products. OMI_NASA has more coverage than OMI_KNMI because of weaker criteria for cloud screening. Also shown is boundary specifications (black lines) of Northern East China analyzed in this study.

large portion of total emissions (summer in particular; see Jaeglé et al., 2005; Wang et al., 2007; Lin et al., 2010b), introducing interference in relating $\mathrm{VCDs}$ of $\mathrm{NO}_{2}$ and anthropogenic sources of $\mathrm{NO}_{\mathrm{x}}$.

Furthermore, emissions of $\mathrm{NO}_{\mathrm{x}}$ in January 2009, differing from the same period in other years, are of particular interest also because of the coincident occurrence of the Chinese New Year (CNY). The CNY is associated with an officially recommended 7-day holiday. Industrial activities are reduced significantly nation-wide during the holiday, and certain industries may be affected for a longer period (i.e., from several days before to several days after the holiday); providing another opportunity to evaluate satellite retrievals in detecting short-term emission reductions. Following the CNY, the dates of the holiday on the Gregorian calendar vary from one year to another: the holiday is held in February in most years while it occurred during 25-31 January for 2009 (Table 1).
The holiday, together with the economic downturn, resulted in the largest year-on-year decline in monthly TPG in January 2009 (Fig. 1). In the present study, the signal in satellite retrievals for holiday-associated reductions in emissions of $\mathrm{NO}_{\mathrm{x}}$ in January 2009 is identified, and is compared with the signal for emission reductions due to the economic downturn.

The present analysis is focused in Northern East China $\left(108.75^{\circ} \mathrm{E}-123.25^{\circ} \mathrm{E}, 29^{\circ} \mathrm{N}-41^{\circ} \mathrm{N}\right.$; see Fig. 2). Covering approximately $17 \%$ of the land area in China, this region is characterized by intensive industrial activity and dense population. It is estimated to have contributed to as much as $55 \%$ of anthropogenic emissions of $\mathrm{NO}_{\mathrm{x}}$ in China in 2006 (Zhang et al., 2009a), resulting in large-scale high values for the VCDs of $\mathrm{NO}_{2}$ (Richter et al., 2005; Stavrakou et al., 2008; van der A et al., 2008; Lin et al., 2010b). In addition, data coverage is relatively good for satellite retrievals 
Table 1. Officially recommended holidays associated with Chinese New Year.

\begin{tabular}{|c|c|c|c|c|c|c|}
\hline Year & 2005 & 2006 & 2007 & 2008 & 2009 & 2010 \\
\hline Dates of holiday & 9-15 February & 29 January-4 February & 18-24 February & 6-12 February & 25-31 January & 13-19 February \\
\hline
\end{tabular}

in this region (Fig. 2), an important factor contributing to a reduction in the uncertainties associated with the representativeness of the data applicable to the analysis of changes in emissions of $\mathrm{NO}_{\mathrm{x}}$.

Sections 2 and 3 introduce Chinese TPG data and four satellite products for VCDs of tropospheric $\mathrm{NO}_{2}$ employed in this study. Section 4 briefly describes the GEOS-Chem model. Section 5 analyzes seasonal and interannual variations in TPG and VCDs of $\mathrm{NO}_{2}$ from October 2004 to February 2010 in response to the changing pace of economic development. Section 6 presents a detailed calculation of the changes in emissions of $\mathrm{NO}_{\mathrm{x}}$ in January from 2005 to 2010 based on the TPG data and satellite products, further quantifying the effects both of the economic downturn and of the CNY on emissions in January 2009. In this section, simulations of GEOS-Chem are used to evaluate the effect of variations in chemistry and meteorology on VCDs of $\mathrm{NO}_{2}$. Section 7 concludes the present study.

\section{Thermal power generation}

Growth in TPG is a relatively good proxy for growth in anthropogenic emissions of $\mathrm{NO}_{\mathrm{x}}$ in China. TPG is estimated to have accounted for approximately $44 \%$ of anthropogenic emissions of $\mathrm{NO}_{\mathrm{x}}$ in 2006 (Zhang et al., 2009a). It is highly correlated with industrial activity which was responsible for $\sim 26 \%$ of $\mathrm{NO}_{\mathrm{x}}$ emissions in 2006 (Zhang et al., 2009a): close to $70 \%$ of total electricity generation was consumed by industry in recent years. According to Zhang et al. (2007), TPG in China grew by a factor of 1.64 from 2000 to 2004, as compared to an increase of 1.48 in anthropogenic emissions of $\mathrm{NO}_{\mathrm{x}}$. The difference reflects effects of changes in emission factors and changes in emissions from the transportation and residential sectors, responsible for $24 \%$ and $6 \%$ of $\mathrm{NO}_{\mathrm{x}}$ emissions in 2006, respectively (Zhang et al., 2007, 2009a).

The unpublished dataset of the National Bureau of Statistics of China for monthly TPG in China from October 2004 to February 2010 are employed in this study as a guide to our estimate of changes in emissions of $\mathrm{NO}_{\mathrm{x}}$. Also included are monthly datasets for total power generation in China from all sources and total power generation for the three regional electricity grids serving the domain of this study (East China Grid, Central China Grid and North China Grid; see McElroy et al. (2009) for geographical specifications of the grids). As shown in Fig. 3b, changes in 12-month power generation for the three regional grids are in excellent agreement with changes in total power generation in China. Thus relative changes in total TPG in the three grids are assumed to be the same as relative changes in total TPG in China. This information will be used to evaluate changes in emissions of $\mathrm{NO}_{\mathrm{x}}$ estimated from interannual variations of VCDs of $\mathrm{NO}_{2}$ retrieved from satellite instruments.

\section{Retrievals of VCDs of tropospheric $\mathrm{NO}_{2}$}

VCDs of tropospheric $\mathrm{NO}_{2}$ retrieved from SCIAMACHY, GOME-2 and OMI are used in this study to evaluate changes in emissions of $\mathrm{NO}_{\mathrm{x}}$ from October 2004 to February 2010. Four products are employed (see Table 2 for detailed descriptions), including the SCIAMACHY and GOME-2 products retrieved by the Royal Netherlands Meteorological Institute (KNMI) (Boersma et al., 2004; Mijling et al., 2009) and two OMI products retrieved independently by KNMI (Boersma et al., 2007) and by the National Aeronautics and Space Administration (NASA) Goddard Space Flight Center (GSFC) (Bucsela et al., 2008). (The two OMI products are identified as OMI_KNMI and OMI_NASA hereafter.) Data for GOME-2 are available since March 2007. SCIAMACHY and GOME-2 pass over China in the morning; OMI in the afternoon. OMI has the largest viewing swath $(2600 \mathrm{~km})$ and the highest horizontal resolution at nadir view (13 km x $24 \mathrm{~km})$, followed by GOME-2 and SCIAMACHY. OMI_NASA uses less strict criteria for cloud screening than OMI_KNMI, resulting in greater data coverage (Fig. 2). Detailed descriptions of key parameters of the retrievals are presented in Table 2. The level-2 data of the three KNMI retrievals are gridded to daily level-3 datasets at a horizontal resolution of $0.25^{\circ}$ long $\times 0.25^{\circ}$ lat; for OMI_NASA, the conversion is implemented by NASA.

Tropospheric VCDs of $\mathrm{NO}_{2}$ are retrieved in three steps. Satellite instruments observe the UV/VIS radiance reflected from the atmosphere. The reflectance is reduced due to absorption by $\mathrm{NO}_{2}$ in the slant column along the pathway of light. This information is used to derive the slant column density ( $\mathrm{SCD}$ ) of $\mathrm{NO}_{2}$. The SCD is partitioned then into separate contributions from the stratosphere and troposphere. Finally, the tropospheric SCD is divided by an air mass factor (AMF) to obtain the tropospheric VCD. For each product, the SCD is derived with the Differential Optical Absorption Spectroscopy (DOAS) technique. In deriving tropospheric SCDs, an assimilation approach utilizing the global CTM TM4 is employed by KNMI to account for the dynamic variability of $\mathrm{NO}_{2}$ in the stratosphere (Boersma et al., 2004; Boersma et al., 2007; Dirksen et al., 2011). With 
Table 2. Properties of $\mathrm{NO}_{2}$ retrievals.

\begin{tabular}{|c|c|c|c|c|}
\hline Instrument & SCIAMACHY & GOME-2 & OMI & OMI \\
\hline Retrieval version & $\mathrm{TM}_{4} \mathrm{NO}_{2} \mathrm{~A}$ v1.10 (level-2) & $\mathrm{TM}_{4} \mathrm{NO}_{2} \mathrm{~A}$ v1.10 (level-2) & DOMINO v1.0.2 (level-2) & $\begin{array}{l}\mathrm{OMNO}_{2} \mathrm{e} \text { (daily level-3), } \\
\text { a.k.a. "Standard Product" }\end{array}$ \\
\hline Onboard satellite & Envisat & MetOp-A & EOS-Aura & EOS-Aura \\
\hline Overpass time over China & $\sim 10: 30 \mathrm{LT}$ & $\sim 10: 00 \mathrm{LT}$ & $\sim 14: 00 \mathrm{LT}$ & $\sim 14: 00 \mathrm{LT}$ \\
\hline Nadir view resolution & $30 \times 60 \mathrm{~km}^{2}$ & $40 \times 80 \mathrm{~km}^{2}$ & $13 \times 24 \mathrm{~km}^{2}$ & $13 \times 24 \mathrm{~km}^{2}$ \\
\hline Viewing swath & $960 \mathrm{~km}$ & $1920 \mathrm{~km}$ & $2600 \mathrm{~km}$ & $2600 \mathrm{~km}$ \\
\hline Spectral resolution & $0.44 \mathrm{~nm}$ & $0.50 \mathrm{~nm}$ & $0.63 \mathrm{~nm}$ & $0.63 \mathrm{~nm}$ \\
\hline Stratospheric contribution & TM4 assimilation & TM4 assimilation & TM4 assimilation & Simplified (see text) \\
\hline Cloud scheme & FRESCO & FRESCO+ & $\mathrm{O}_{2}-\mathrm{O}_{2}$ & $\mathrm{O}_{2}-\mathrm{O}_{2}$ \\
\hline Cloud screening & Cloud radiance $<50 \%^{\mathrm{a}}$ & Cloud radiance $<50 \% \mathrm{a}$ & Cloud radiance $<50 \%$ a & Cloud fraction $<30 \%$ \\
\hline Surface reflectivity & TOMS + GOME & TOMS + GOME & $\mathrm{TOMS}+\mathrm{GOME}^{\mathrm{b}}$ & GOME \\
\hline A priori vertical profile of $\mathrm{NO}_{2}$ & TM4 simulations & TM4 simulations & TM4 simulations & Time independent \\
\hline
\end{tabular}

a (Over Northern East China in January months) For SCIAMACHY, the cloud fraction is always less than $25 \%$, and is less than $15 \%(20 \%)$ for $88 \%$ (99.6\%) of the cases. For GOME-2, the cloud fraction is always less than $31 \%$, and is less than $15 \%$ (20\%) for $74 \%$ (94\%) of the cases. For OMI_KNMI, the cloud fraction is always less than $32 \%$, and is less than $15 \%(20 \%)$ for $76 \%(93 \%)$ of the cases.

b Since 17 Feburary 2009, the surface reflectance dataset based on OMI measurements was used.

respect to OMI_NASA, the contribution from stratospheric $\mathrm{NO}_{2}$ is derived by selecting SCDs at locations where the influence of tropospheric $\mathrm{NO}_{2}$ is not expected to be significant, smoothing meridionally with a boxcar function, followed by a zonal planetary wave analysis up to wave-2 (Bucsela et al., 2008). The calculation of AMF also differs significantly between the approaches by KNMI and by NASA, differences which contribute significantly to uncertainties in the ultimately retrieved values for VCDs of $\mathrm{NO}_{2}$. Errors in AMF result from inaccuracies in assumptions concerning surface albedo, cloud fraction, cloud pressure, and the a priori vertical profile adopted for tropospheric $\mathrm{NO}_{2}$. SCIAMACHY and GOME-2 employ information on surface reflectance derived from TOMS (Herman and Celarier, 1997) and GOME (Koelemeijer et al., 2003). OMI_KNMI also employs the TOMS/GOME dataset prior to 17 Feburary 2009, since when a new reflectance dataset based on OMI measurements is used. OMI_NASA utilizes information based on GOME alone for surface reflectance. For cloud parameters, the methods of FRESCO (Koelemeijer et al., 2001), FRESCO+ (Wang et al., 2008) and $\mathrm{O}_{2}-\mathrm{O}_{2}$ (Acarreta et al., 2004) are used for SCIAMACHY, GOME-2 and OMI (both by KNMI and by NASA), respectively. In calculating the AMF, the vertical profile of $\mathrm{NO}_{2}$ has to be predetermined. The KNMI retrievals make use of real-time profiles simulated by TM4 (Boersma et al., 2004; Boersma et al., 2007). In OMI_NASA, a constant annually-averaged vertical profile simulated by GEOS-Chem is used for each location (Bucsela et al., 2008). More analyses and validations of the re- trievals are discussed in previous studies (Boersma et al., 2004; Boersma et al., 2007; Bucsela et al., 2008; Boersma et al., 2009; Zhou et al., 2009; Hains et al., 2010; Lamsal et al., 2010; Lin et al., 2010b).

Systematic biases have been identified in the retrieval products (Boersma et al., 2008; Bucsela et al., 2008; Boersma et al., 2009; Zhou et al., 2009; Hains et al., 2010; Lamsal et al., 2010; Lin et al., 2010b). It is estimated that VCDs retrieved by KNMI may be overestimated by up to $40 \%$ based on in situ measurements in Europe and the US (Boersma et al., 2009; Zhou et al., 2009; Hains et al., 2010; Lin et al., 2010b), with a bias in winter higher than in summer (Boersma et al., 2011). Lamsal et al. (2010) found significant errors over the US in the seasonality of VCDs in OMI_NASA attributed partly to the use of time independent a priori vertical profiles for $\mathrm{NO}_{2}$. Retrieval errors are expected also for China, though they cannot be quantified currently due to lack of accurate in situ measurements.

Recently, several improvements have been made to reduce retrieval errors in OMI_KNMI (Boersma et al., 2011); to date most improvements have been applied only to data over 2004-June 2008 (see www.temis.nl). In particular, a new look-up table (LUT) for radiative transfer calculation is implemented, resulting in a $17 \%$ reduction in retrieved VCDs of $\mathrm{NO}_{2}$ over East Asia (Boersma et al., 2011). Inaccuracies in the old LUT (for retrievals analyzed here) are consistent in time and thus should not introduce significant errors in our trend analysis. Since 17 Feburary 2009, OMI_KNMI employs the surface reflectance dataset based 
(a)

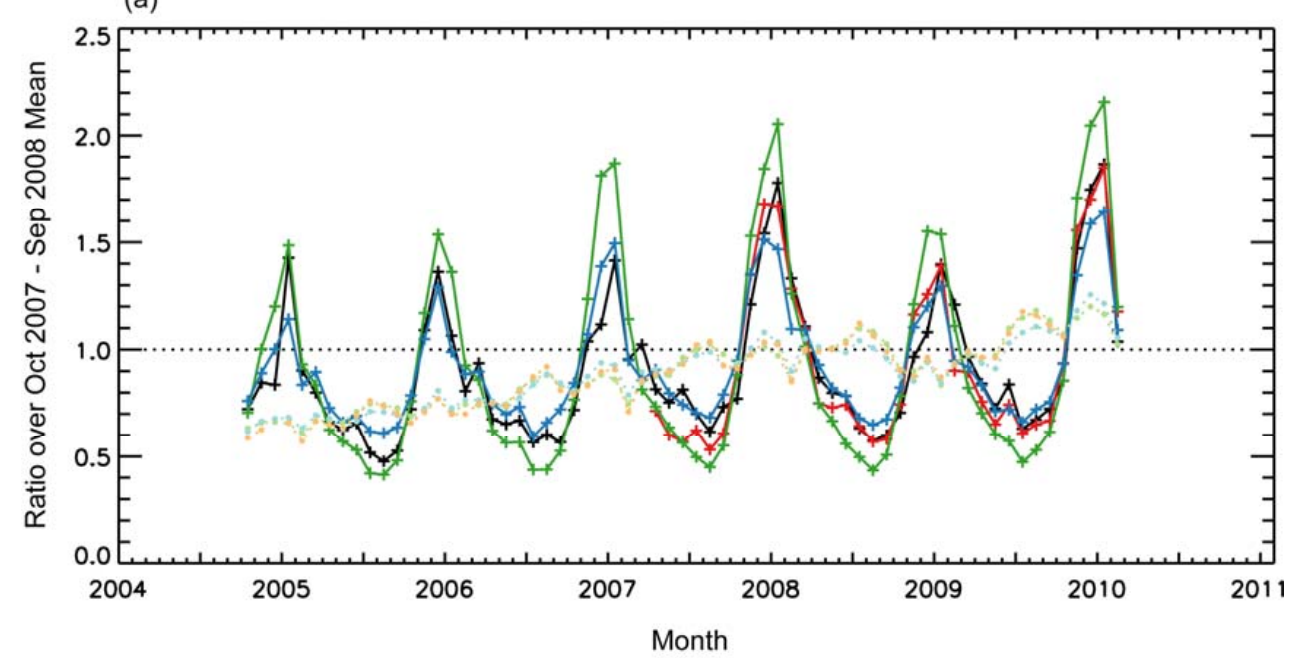

(b)

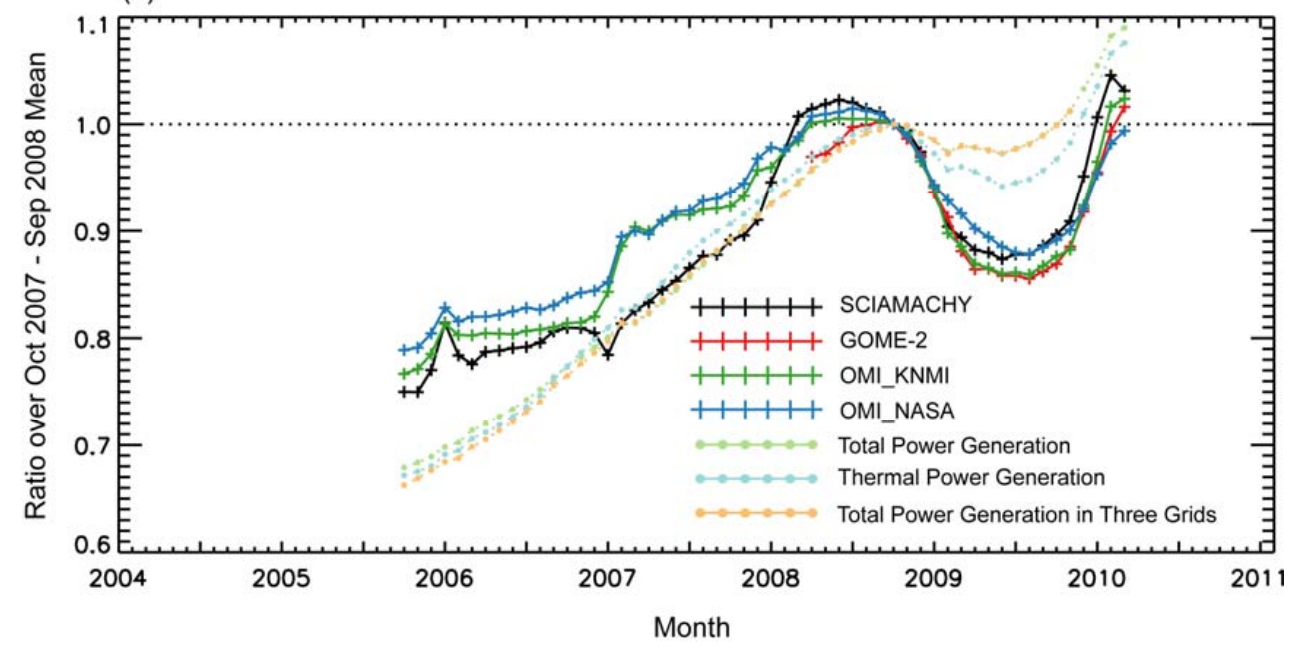

Fig. 3. (a) Monthly variations in regional mean $\mathrm{VCDs}$ of $\mathrm{NO}_{2}$ and power generation in China relative to values averaged over the 12-month period of October 2007-September 2008. (b) Corresponding variations after a 12-month moving average: each point represents the mean over prior 12 months; and an increase (decrease) of value denotes a year-on-year increase (decrease) in VCDs of $\mathrm{NO}_{2}$ or power generation.

on OMI measurements in place of the previous dataset from TOMS/GOME. The change results in a reduction of retrieved VCDs by about $5 \%$ over East Asia (Boersma et al., 2011). It does not affect our analysis of the $\mathrm{NO}_{2}$ trend prior to February 2009 and of the impacts of economic downturn and CNY for January 2009. The updated retrieval also reduces errors in the a priori vertical profile of $\mathrm{NO}_{2}$ (Boersma et al., 2011). Errors in the a priori profile, however, are not important for quantifying emissions of $\mathrm{NO}_{\mathrm{x}}$ in the present analysis, since the (day-to-day varying) averaging kernel is employed in calculating modeled VCDs of $\mathrm{NO}_{2}$ (see Sect. 4) to compare with retrieved values. Other improvements are minor and not important for the present analysis, including a cross-track stripe correction and a high-resolution surface height dataset (Boersma et al., 2011).

\section{GEOS-Chem}

GEOS-Chem (http://wiki.seas.harvard.edu/geos-chem/ index.php/Main_Page) is a global CTM used worldwide to study tropospheric chemistry. Version 8.1.1 of the model is used in this study, with a major update by employing the non-local scheme (Holtslag and Boville, 1993) to simulate mixing in the PBL in place of the assumption of a fully-mixed PBL (This update has been standardized since Version 8.2.2). The model was run with the full Ox-CO-NO - -VOC-HOx chemistry at a resolution of $2.5^{\circ}$ long $\times 2^{\circ}$ lat with 47 vertical layers. It was driven by the assimilated meteorological fields of GEOS-5 produced by the NASA Global Modeling and Assimilation Office (GMAO). Anthropogenic emissions in Asia representative of 2006 taken from the INTEX-B mission are used for $\mathrm{NO}_{\mathrm{x}}$, 
carbon monoxide ( $\mathrm{CO}$ ) and non-methane volatile organic compounds (NMVOC) (Zhang et al., 2009). They were held constant in simulations for all years. Detailed model setup was described by Lin and McElroy (2010) and Lin et al. (2010b).

Model errors in simulating VCDs of $\mathrm{NO}_{2}$ result from inaccuracies in the calculation of the lifetime of $\mathrm{NO}_{\mathrm{x}}$ and the partitioning between $\mathrm{NO}_{2}$ and $\mathrm{NO}$ (Martin et al., 2003; Martin et al., 2006). In particular, the heterogeneous reaction of $\mathrm{N}_{2} \mathrm{O}_{5}$ with liquid water on the surface of aerosols is a major loss pathway of $\mathrm{NO}_{\mathrm{x}}$ in winter. The current model uses the rate of uptake of $\mathrm{N}_{2} \mathrm{O}_{5}$ by aerosols compiled by Evans and Jacob (2005). More recent measurements of Bertram et al. (2009) and Brown et al. (2009) suggested that the actual rate of uptake may be lower than assumed by Evans and Jacob (2005), by up to an order of magnitude in some cases. The two studies differ, however, in the importance for the uptake of $\mathrm{N}_{2} \mathrm{O}_{5}$ of environmental parameters such as relative humidity and aerosol compositions (Bertram et al., 2009; Brown et al., 2009). Our preliminary sensitivity analysis for January 2009 using the nested version of the model $\left(0.667^{\circ}\right.$ long $\times 0.5^{\circ}$ lat) showed that reducing the rate of uptake by a factor of 10 resulted in an increase by $13-18 \%$ in modeled regional mean VCDs of $\mathrm{NO}_{2}$ for Northern East China. Other sources of model errors relate to the concentration of $\mathrm{OH}$ affecting the $\mathrm{NO}_{2}+\mathrm{OH}$ reaction, the amount of aerosols affecting the uptake of $\mathrm{N}_{2} \mathrm{O}_{5}$, the formation of organic nitrates, the concentration of ozone affecting the partitioning between $\mathrm{NO}_{2}$ and $\mathrm{NO}$, as well as likely errors in meteorological parameters. Overall, model errors are estimated to be about 30-40\%, based on previous studies (Martin et al., 2003; Wang et al., 2007; Lin et al., 2010b).

In calculating modeled VCDs of $\mathrm{NO}_{2}$ for comparisons with the three KNMI retrievals, the averaging kernel (AK) was applied to simulated vertical distributions of $\mathrm{NO}_{2}$ to eliminate the effect of errors in the a priori vertical profiles of $\mathrm{NO}_{2}$ assumed in the retrieval process. For OMI_NASA, the associated AK is not available, thus retrieved VCDs are compared with modeled VCDs both with and without applying the AK taken from OMI_KNMI. Unless stated otherwise, AK's are accounted for in all of the modeled VCDs analyzed in the subsequent sections.

\section{General variations in TPG and retrieved VCDs of $\mathrm{NO}_{2}$ over October 2004-February 2010}

This section analyzes general changes in thermal power generation (TPG) and retrieved VCDs of $\mathrm{NO}_{2}$ over October 2004-February 2010, providing an overall picture of the seasonality and interannual variability of both data to facilitate the emission analysis in Sect. 6. Discussions for interannual variation are focused on the 12-month mean values, after implementing a 12-month moving average to both data series. A more detailed analysis is presented in Sect. 6 for January months to quantify emissions of $\mathrm{NO}_{\mathrm{x}}$ and effects of the economic downturn and the CNY.

\subsection{Variations in TPG over October 2004- February 2010}

As shown in Fig. 3b, Chinese TPG grew significantly and relatively linearly until the economic downturn that set in around late 2008. The 12-month average TPG increased by $49 \%$ from 5.23 terawatt hours per day ( TWh day $^{-1}$ ) between October 2004 and September 2005 to 7.79 TWh day $^{-1}$ between October 2007 and September 2008. It then decreased by as much as $6 \%$ under the influence of the downturn. Simultaneously, there was a reduction by about $3 \%$ in the 12 month average total power generation. The decrease in TPG was more significant than the decrease in total power generation reflecting the preference to reduce thermal power rather than cleaner sources of energy (hydro power, nuclear power, etc.). Starting from mid 2009, growth of power generation resumed in pace with the recovery of the economy.

The TPG also varies month to month in response to seasonal variation in energy demand (Fig. 3a). It increases in summer and winter to meet the demand for air conditioning and heating, respectively (Zhang et al., 2007). The TPG minimum normally occurs in February in conjunction with the CNY which results in large-scale reductions in industrial activities and energy demand.

\subsection{Variations in retrieved VCDs of $\mathrm{NO}_{2}$ over October 2004-February 2010}

\subsubsection{Seasonal variability}

The seasonal variation of VCDs of $\mathrm{NO}_{2}$ differs significantly from that of power generation (Fig. 3a). $\mathrm{VCDs}$ of $\mathrm{NO}_{2}$ reach a maximum in winter due to increases in anthropogenic emissions associated with domestic heating and, more importantly, increases in the atmospheric lifetime of $\mathrm{NO}_{\mathrm{x}}$ as a result of reduced photochemical activity. In particular, the lifetime of $\mathrm{NO}_{\mathrm{x}}$ in winter is 3-5 times longer than in summer (Martin et al., 2003; Lin and McElroy, 2010). The minimum VCDs of $\mathrm{NO}_{2}$ occur in summer when $\mathrm{NO}_{\mathrm{x}}$ is removed rapidly through reaction with the hydroxyl radical. Emissions of $\mathrm{NO}_{\mathrm{x}}$ from lightning and soil are greatest in this season. The enhanced natural sources tend to increase VCDs of $\mathrm{NO}_{2}$, while their effects are more than offset by the negative effect of the shorter lifetime. In general, VCDs of $\mathrm{NO}_{2}$ decrease by a factor of 3-7 from winter to summer (Fig. 3a).

The seasonality of VCDs of $\mathrm{NO}_{2}$ differs between the four retrieval products (Fig. 3a). OMI_KNMI suggests the strongest seasonality in $\mathrm{NO}_{2}$. Values of OMI_NASA exceed OMI_KNMI in summer, while they are much smaller than OMI_KNMI in winter. The differences are in part because the overestimate of OMI_KNMI is larger in winter than in summer (Boersma et al., 2011). Furthermore, OMI_NASA 
uses an annually-averaged a priori vertical profile for $\mathrm{NO}_{2}$ for all seasons and does not account for increases in the PBL mixing from winter to summer (Lamsal et al., 2010). As the sensitivity of satellite instruments increases with the height of $\mathrm{NO}_{2}$ in the troposphere, a given amount of radiance received by the instruments can be interpreted by the retrieval algorithm as either more $\mathrm{NO}_{2}$ at a higher altitude or less $\mathrm{NO}_{2}$ at a lower altitude. An annual average a priori vertical profile for $\mathrm{NO}_{2}$ tends to result in an overestimate of tropospheric VCDs retrieved for summer with an underestimate for winter. Another difference between the two retrievals is associated with the allocation of $\mathrm{NO}_{2}$ to the stratosphere and troposphere. OMI_KNMI attributes more $\mathrm{NO}_{2}$ to the stratosphere than OMI_NASA, and the difference is greatest in winter (Lamsal et al., 2010; Dirksen et al., 2011). This factor, however, cannot account for the larger seasonality of VCDs in OMI_KNMI as compared to OMI_NASA.

For the three KNMI products, the seasonality of $\mathrm{NO}_{2}$ in SCIAMACHY and GOME-2 is smaller than OMI_KNMI (Fig. 3a). This may be partially because SCIAMACHY and GOME-2 pass over China in the mid morning while OMI passes in the early afternoon when the mechanisms for $\mathrm{NO}_{\mathrm{x}}$ sink differ to some extent. For the two loss pathways of $\mathrm{NO}_{\mathrm{x}}$, the $\mathrm{NO}_{2}+\mathrm{OH}$ reaction depends on solar radiation; thus it is more important in the afternoon than in the morning, and is subject to larger seasonal variation than the $\mathrm{N}_{2} \mathrm{O}_{5}+\mathrm{H}_{2} \mathrm{O}$ pathway. Therefore the seasonality of the lifetime of $\mathrm{NO}_{\mathrm{x}}$ in the afternoon is greater than that in the morning, as indicated by our model simulations.

\subsubsection{Interannual trend}

Despite differences in seasonality between retrieved VCDs of $\mathrm{NO}_{2}$ and TPG, interannual trends of VCDs were generally consistent with trends in TPG (Fig. 3b). From October 2004 to September 2008, 12-month mean VCDs of $\mathrm{NO}_{2}$ increased by $33 \%, 30 \%$ and $27 \%$ for SCIAMACHY, OMI_KNMI and OMI_NASA, respectively, as compared to the increase of $49 \%$ in TPG. The smaller increases in VCDs may be attributed in part to the overall reduction in emission factors during the time period, as inferred from the findings of Zhang et al. (2007) for previous years. Other factors may include changes in chemical and meteorological conditions affecting the lifetime of $\mathrm{NO}_{\mathrm{x}}$, and/or natural sources of $\mathrm{NO}_{\mathrm{x}}$ that did not change significantly over the years.

The effect of slowing industrial activities due to the economic downturn is evident in retrieved VCDs of $\mathrm{NO}_{2}$ (Fig. 3b). The four retrieval products suggest that the 12month mean VCD of $\mathrm{NO}_{2}$ from mid 2008 to mid 2009 was $12-14 \%$ lower than the mean value over mid 2007-mid 2008. The reductions were about twice as large as the reduction in TPG because of the timing of the economic downturn together with the differences in seasonality between TPG and VCDs. The downturn was most intense during the 20082009 winter (Fig. 1). In addition, the VCD of $\mathrm{NO}_{2}$ reaches a maximum in winter (Fig. 3a), thus its winter value contributes to the 12-month average more than values in other seasons. By comparison, the seasonality of TPG is much smaller (Fig. 3a), thus values in individual seasons contribute more evenly to the 12-month average. Therefore, a given relative increase of values in winter has a larger impact on the 12-month mean for $\mathrm{VCDs}$ of $\mathrm{NO}_{2}$ and a smaller impact for TPG.

\section{Quantifying year-on-year emission changes for January and effect of the economic downturn}

In this section, a detailed derivation is provided to quantify year-on-year changes in emissions of $\mathrm{NO}_{\mathrm{x}}$ for January over 2005-2010, identifying the causes of the emission anomaly in January 2009. In particular, the interannual variation of emissions for January is quantified in Sects. 6.1 and 6.2 by employing data for TPG, retrievals for VCDs of $\mathrm{NO}_{2}$, and simulations of GEOS-Chem. In Sect. 6.3, the analysis is focused on emission reductions from January 2008 to January 2009 , distinguishing the impact of the economic downturn for January 2009 from the effect of the CNY.

\subsection{TPG-inferred changes in emissions of $\mathrm{NO}_{\mathrm{x}}$}

The TPG in January increased between 2005 and 2010 except for the reduction from 2008 to 2009 (Fig. 4c). It increased by $51 \%$ from 2005 to 2008 , decreased by $18 \%$ from 2008 to 2009 , and increased again by $43 \%$ from 2009 to 2010. The relatively low TPG in January 2009 was a result of the economic downturn compounded by the impact of the CNY.

Emissions of $\mathrm{NO}_{\mathrm{x}}$ from TPG are estimated to have decreased from January 2008 to January 2009 by the same amount as the reduction in TPG. This is a reasonable approximation as emission factors should not change significantly over the 1-yr period. The low TPG in January 2009 was driven mainly by reduced electricity demand from industry because of the economic downturn and the $\mathrm{CNY}$, while electricity demand for residential use may have remained relatively constant. Thus reductions of emissions from industry (residences) may be larger (smaller) than $18 \%$, provided that emission factors for these two sectors remained relatively constant from January 2008 to January 2009. Meanwhile, emissions from transportation may be affected to some extent both by the economic downturn and by the CNY. Considering the major contribution of TPG and industry to emissions of $\mathrm{NO}_{\mathrm{x}}$, it is estimated that total anthropogenic emissions of $\mathrm{NO}_{\mathrm{x}}$ decreased by $18 \%$ from January 2008 to January 2009. This independent information is used to evaluate changes in emissions derived from satellite retrievals. 

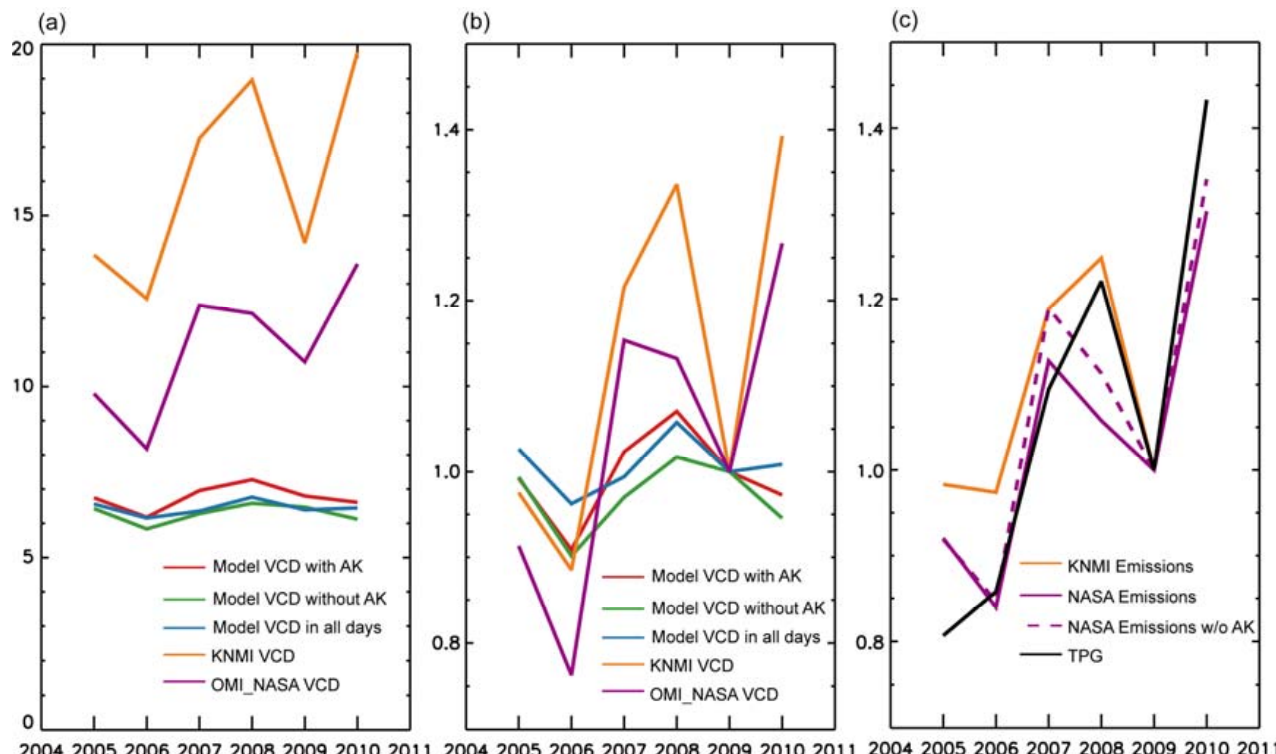

Fig. 4. (a) Changes in January mean VCDs of $\mathrm{NO}_{2}\left(10^{15}\right.$ molec $\left.\mathrm{cm}^{-2}\right)$ from 2005 to 2010 with respect to OMI retrievals. (b) Corresponding changes in VCDs of $\mathrm{NO}_{2}$ relative to values in January 2009. (c) Changes in emissions of $\mathrm{NO}_{\mathrm{x}}$ derived from OMI relative to values in January 2009; also shown is changes in TPG $\left(\mathrm{TWh}_{\text {day }}{ }^{-1}\right.$ ) relative to January 2009. See Sect. 6.2 for the derivation of emissions of $\mathrm{NO}_{\mathrm{x}}$.

\subsection{Changes in emissions of $\mathrm{NO}_{\mathrm{x}}$ in January derived from satellite retrievals}

Emissions of $\mathrm{NO}_{\mathrm{x}}$ can be derived from retrievals of $\mathrm{NO}_{2}$ based on the mass balance approximation (Martin et al., 2003). Neglecting the effect of horizontal transport, the VCD of $\mathrm{NO}_{2}$ is determined by emissions of $\mathrm{NO}_{\mathrm{x}}$, the atmospheric lifetime of $\mathrm{NO}_{\mathrm{x}}$, and the partitioning between $\mathrm{NO}_{2}$ and nitric oxide (NO), i.e., $\Omega=E \cdot \alpha$, where $\Omega$ denotes the VCD of $\mathrm{NO}_{2}, E$ denotes emissions of $\mathrm{NO}_{\mathrm{x}}$, and $\alpha$ denotes the combined effect of the lifetime of $\mathrm{NO}_{\mathrm{x}}$ and the partitioning between $\mathrm{NO}_{2}$ and NO. Consequently, $E=\Omega / \alpha$. The reader is referred to Martin et al. (2003) and Lin et al. (2010b) for a detailed derivation.

The magnitude of $\alpha$ is determined by chemical and meteorological conditions. In this study, it is simulated by GEOSChem for each January: $\alpha=\Omega_{\mathrm{m}} / E_{\mathrm{m}}$. Here $\Omega_{\mathrm{m}}$ indicates modeled $\mathrm{VCD}$ of $\mathrm{NO}_{2}$ and $E_{\mathrm{m}}$ denotes emission inputs for the CTM. Consequently, emissions of $\mathrm{NO}_{\mathrm{x}}$ can be derived from retrieved VCDs of $\mathrm{NO}_{2}: E_{\mathrm{r}}=\Omega_{\mathrm{r}} / \alpha=\Omega_{\mathrm{r}} / \Omega_{\mathrm{m}} \cdot E_{\mathrm{m}}$, where the subscript " $r$ " denotes retrievals.

Of particular interest are variations in emissions of $\mathrm{NO}_{\mathrm{x}}$ for January across the years. The ratio of emissions over a reference month is $R_{\mathrm{e}}=E_{\mathrm{r}} / E_{\mathrm{r} 0}=\left(\Omega_{\mathrm{r}} / \Omega_{\mathrm{r} 0}\right) /\left(\Omega_{\mathrm{m}} / \Omega_{\mathrm{m} 0}\right) \cdot\left(E_{\mathrm{m}} / E_{\mathrm{m} 0}\right)$, where the subscript " 0 " denotes the reference month. In this study, the reference month is chosen to be January 2009 in order to better define the impact of the economic downturn. Furthermore, $E_{\mathrm{m}} \approx E_{\mathrm{m} 0}$ since model inputs for anthropogenic emissions are the same for all months and other sources of $\mathrm{NO}_{\mathrm{x}}$ are negligible in January (Jaeglé et al., 2005; Lin and McElroy, 2010). Therefore one gets $R_{\mathrm{e}}=R_{\mathrm{r}} / R_{\mathrm{m}}$, where $R_{\mathrm{r}}=\Omega_{\mathrm{r}} / \Omega_{\mathrm{r} 0}$ and $R_{\mathrm{m}}=\Omega_{\mathrm{m}} / \Omega_{\mathrm{m} 0}$ representing retrieved and modeled changes in VCDs of $\mathrm{NO}_{2}$ relative to January 2009 , respectively. To ensure consistency with $R_{\mathrm{r}}, R_{\mathrm{m}}$ is calculated based on model results sampled from days with valid satellite data and applied with the averaging kernel. Analysis is then conducted for $R_{\mathrm{r}}, R_{\mathrm{m}}$ and $R_{\mathrm{e}}$ in Sects. 6.2.1 and 6.2.2 for individual retrieval products.

As discussed in Sects. 3 and 4, errors exist in retrieval products and model simulations. These errors, together with inaccuracies in emission inputs for the CTM, result in large differences between retrieved and modeled $\mathrm{VCDs}$ of $\mathrm{NO}_{2}$ for individual months (see Appendix A). Their impact on derived changes in emissions of $\mathrm{NO}_{\mathrm{x}}$ is evaluated in Sects. 6.2.1 and 6.2.2 using the independent estimate based on data for TPG. In addition, the emission derivation here does not take into account the effects of changing emissions of $\mathrm{NO}_{\mathrm{x}}, \mathrm{CO}$ or NMVOC on the nitrogen chemistry under specified meteorological conditions. The effects, however, are not expected to be important in this study (see Appendix B). Furthermore, horizontal transport may affect the emission derivation for individual locations due to a relatively long lifetime of $\mathrm{NO}_{\mathrm{x}}$ in January. However, the present study focuses mainly in Northern East China as a whole (with large area), and transport within the region does not significantly affect the total abundance of $\mathrm{NO}_{\mathrm{x}}$ in the region. In this case, the effect of horizontal transport is expected to be small and can be neglected appropriately (Lin and McElroy, 2010). 


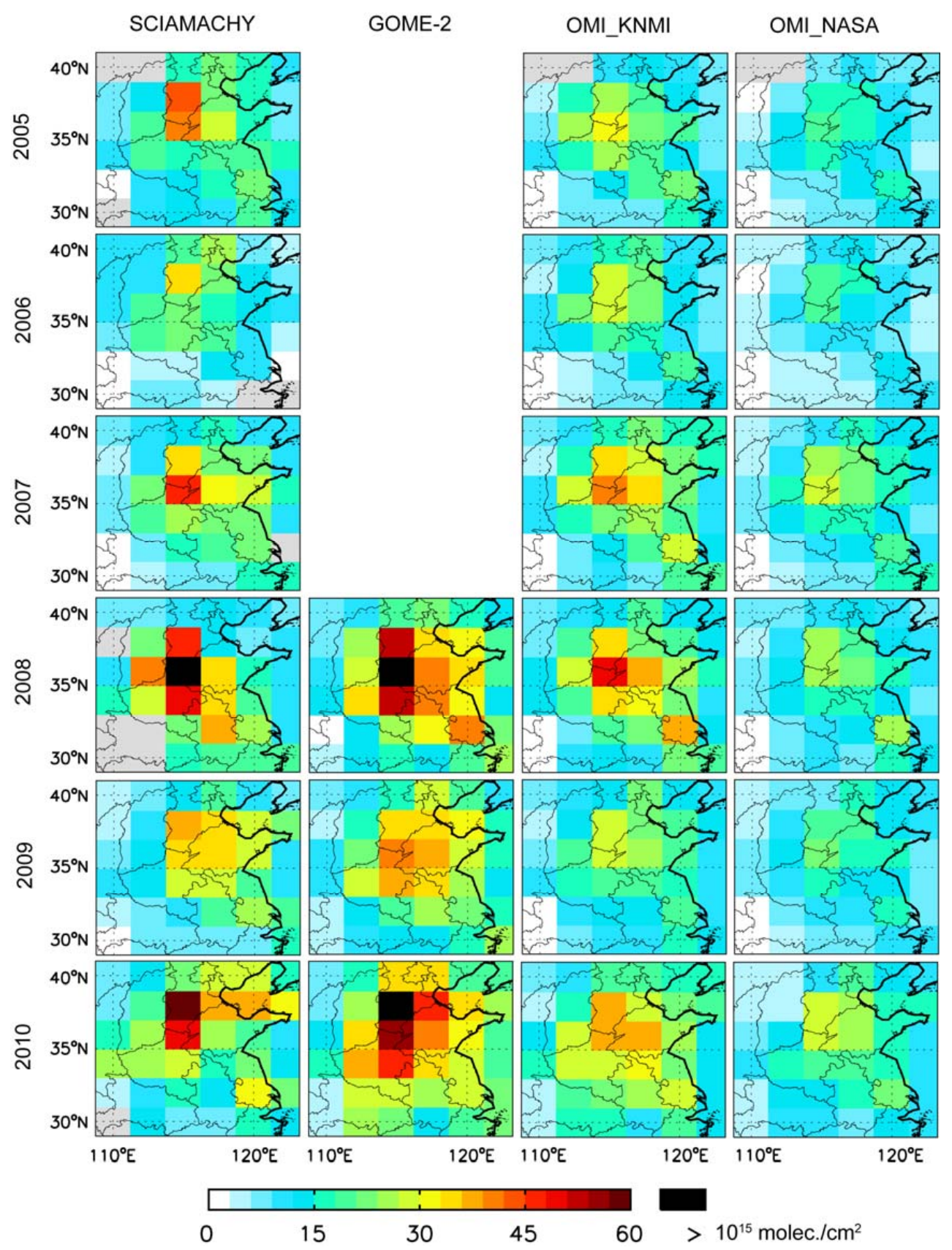

Fig. 5. Spatial distributions of retrieved VCDs of $\mathrm{NO}_{2}$ in January over Northern East China. Data are presented at the model resolution of $2.5^{\circ}$ long $\times 2^{\circ}$ lat. Areas in grey color do not have valid retrievals.

\subsubsection{Changes in emissions of $\mathrm{NO}_{\mathrm{x}}$ derived from OMI_KNMI}

Changes from 2005 to 2010 in January mean VCD of $\mathrm{NO}_{2}$ for OMI_KNMI are generally consistent across Northern East China (Fig. 5). Averaged over the region, the VCD decreased by $9 \%$ from 2005 to 2006, increased by $51 \%$ from 2006 to 2008, and then decreased by $25 \%$ from 2008 to 2009 (Fig. 4a, b). Values specified here are determined by changes in emissions and many other factors (chem$\mathrm{ical} /$ meteorological conditions, data availability, averaging kernel, etc.). Factors other than emissions are analyzed in detail in Appendix C.

Changes in January mean emissions of $\mathrm{NO}_{\mathrm{x}}$ derived from OMI_KNMI are shown in Fig. 4c and Fig. 7. Compared to changes in TPG, increases in emissions are more moderate from 2005 to 2008 attributed likely to decreases in emission factors (Zhang et al., 2007; Zhao et al., 2009). From 2008 


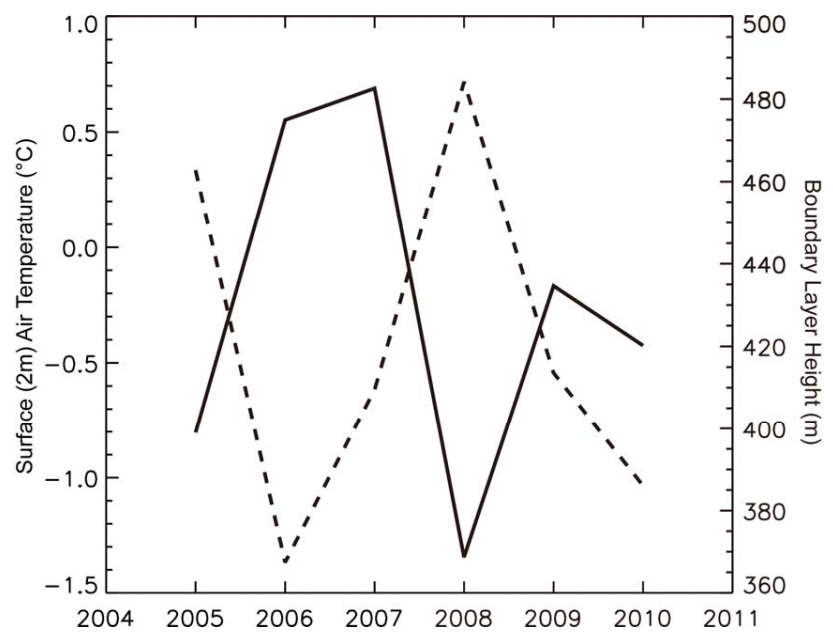

Fig. 6. Variations from 2005 to 2010 of January mean surface (2m) air temperature (solid line) and planetary boundary layer height (dashed line) over Northern East China.

to 2009 and then from 2009 to 2010 , emissions of $\mathrm{NO}_{\mathrm{x}}$ first decreased by $20 \%$ and then rebounded by $43 \%$, close to the changes in TPG (Fig. 4c).

\subsubsection{Changes in emissions of $\mathrm{NO}_{\mathrm{x}}$ derived from other retrieval products}

Changes in emissions of $\mathrm{NO}_{\mathrm{x}}$ for January from 2005 to 2010 can be derived from the other three retrievals using the same approach as that for OMI_KNMI.

OMI_NASA assumes time-invariant a priori vertical profiles for $\mathrm{NO}_{2}$ and does not provide the $\mathrm{AK}$. Thus, in deriving the emissions, simulated VCDs of $\mathrm{NO}_{2}$ both with and without applying the AK taken from OMI_KNMI were used to approximate the effects of chemistry and meteorology. As shown in Figs. 4a, b and 5, VCDs in OMINASA differ from OMI_KNMI throughout the years, as a result of differences both in retrieval methods and in criteria for valid data (see details in Sect. 3 and Table 2). Values of OMI_NASA decreased more significantly from 2005 to 2006, decreased slightly from 2007 to 2008 , and decreased by $12 \%$ only from 2008 to 2009. As a result, changes in emissions estimated from OMI_NASA differ significantly from those derived from OMI_KNMI (Figs. 4c and 7). More importantly, they are not consistent with the changes indicated by the TPG data. In particular, there is a slight reduction from 2007 to 2009 (Fig. 4c; both purple lines) that is not seen in the TPG data.

Changes in GOME-2 and associated model VCDs are consistent with changes in OMI_KNMI and associated model values, although with different magnitudes (Fig. 8b). Derived based on GOME-2, emissions of $\mathrm{NO}_{\mathrm{x}}$ in January decreased by $10 \%$ from 2008 to 2009 and increased by $35 \%$ from 2009 to 2010 (Figs. 7 and 8c). The sign of emission changes is consistent with that for TPG while the magnitude is smaller, particularly for the reduction from 2008 to 2009 .

VCDs retrieved from SCIAMACHY are influenced by variations in chemical and meteorological conditions across the years, as suggested by model results (sampled at the overpass time of the instrument from all days) showing that the minimum value in January 2006 differs from the maximum in January 2008 by about $18 \%$ (Fig. 9b; blue line). This is consistent with the finding for OMI_KNMI in Appendix C. The SCIAMACHY product suffers greatly from the lack of valid data (Fig. 2), and the effect of incomplete sampling is much greater than the effects for OMI and GOME-2 that have better data coverage. This is evident by the large differences between model VCDs sampled from all days and those sampled from days with valid satellite data, particularly for January 2008 (Fig. 9a, b; blue lines versus green lines). As a result, emissions of $\mathrm{NO}_{\mathrm{x}}$ derived from SCIAMACHY are also affected significantly by inadequate data coverage: they were nearly constant between 2007 and 2009 (Fig. 9c), inconsistent with the changes in TPG.

Overall, changes in emissions of $\mathrm{NO}_{\mathrm{x}}$ derived from OMI_KNMI seem to best capture the changes inferred from TPG. Therefore OMI_KNMI is used in the following section to quantify the individual effects of the economic downturn and $\mathrm{CNY}$ on emissions of $\mathrm{NO}_{\mathrm{x}}$ in January 2009.

\subsection{Effect of the economic downturn versus CNY}

Three approaches are proposed in the study to separate the impact of the downturn from that of CNY for January 2009. The impact of CNY can be estimated from the TPG data. CNY occurred in February in 2005, 2007, 2008, and 2010 (Table 1). For these years, CNY is assumed to be the sole cause of differences in daily TPG between January and February. Its effect is calculated then as the reduction of daily TPG from January to February, which amounts to about $8 \%$ for $2005,15 \%$ for 2007 , and $13 \%$ for both 2008 and 2010 . The effect of CNY is estimated accordingly as the average of these values, i.e., a reduction of $12 \%$ with a standard deviation of $3 \%$.

The CNY holiday in 2009 took place over 25-31 January with large impacts on economic activities. Industrial production may not have fully resumed by early February. For this year, the effect of CNY may be allocated mainly to January and to a lesser extent to February. Assuming the CNY affected January 2009 alone and that its impact on industrial activities was independent of the economic downturn, it is estimated that, of the total of $18 \%$ reduction in daily TPG from January 2008 to January 2009, the CNY resulted in a reduction of $12 \%$ while the downturn led to a reduction of $7 \%$. Assuming a smaller impact of CNY in January 2009, at $10 \%$, the effect of the downturn is estimated to be $9 \%$.

A similar analysis is applied to emissions of $\mathrm{NO}_{\mathrm{x}}$ derived from OMI_KNMI, assuming that CNY affected daily emissions in the same way as it influenced daily TPG. For a 


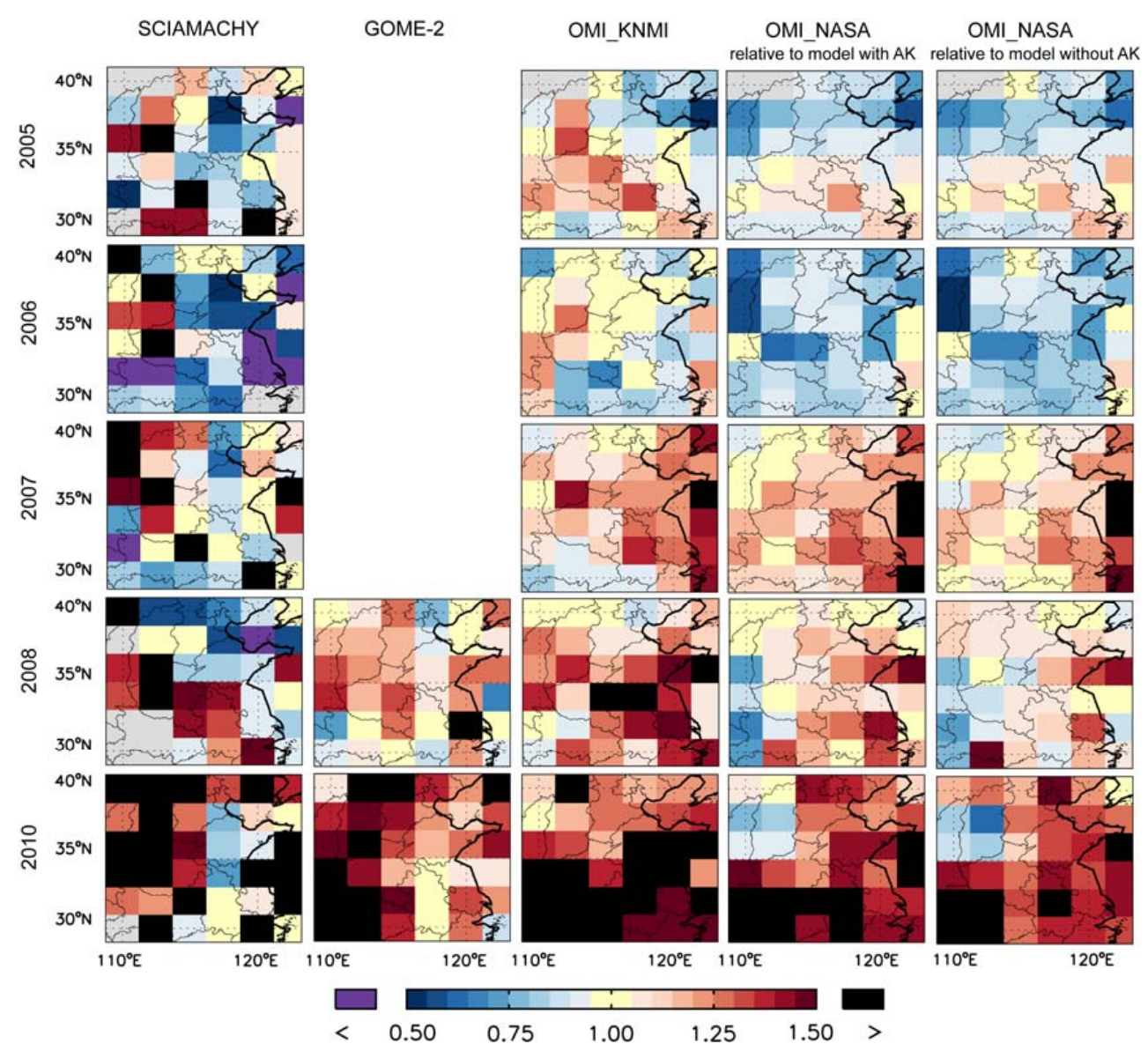

Fig. 7. Ratios of derived emissions of $\mathrm{NO}_{\mathrm{x}}$ in January of 2005-2010 over emissions in January 2009 in Northern East China. Plots for 2009 are skipped as the values are uniformly unity. Data are presented at the model resolution of $2.5^{\circ}$ long $\times 2^{\circ}$ lat. Areas in grey color do not have valid retrievals. See Sect. 6.2 for the derivation of emissions of $\mathrm{NO}_{\mathrm{x}}$.
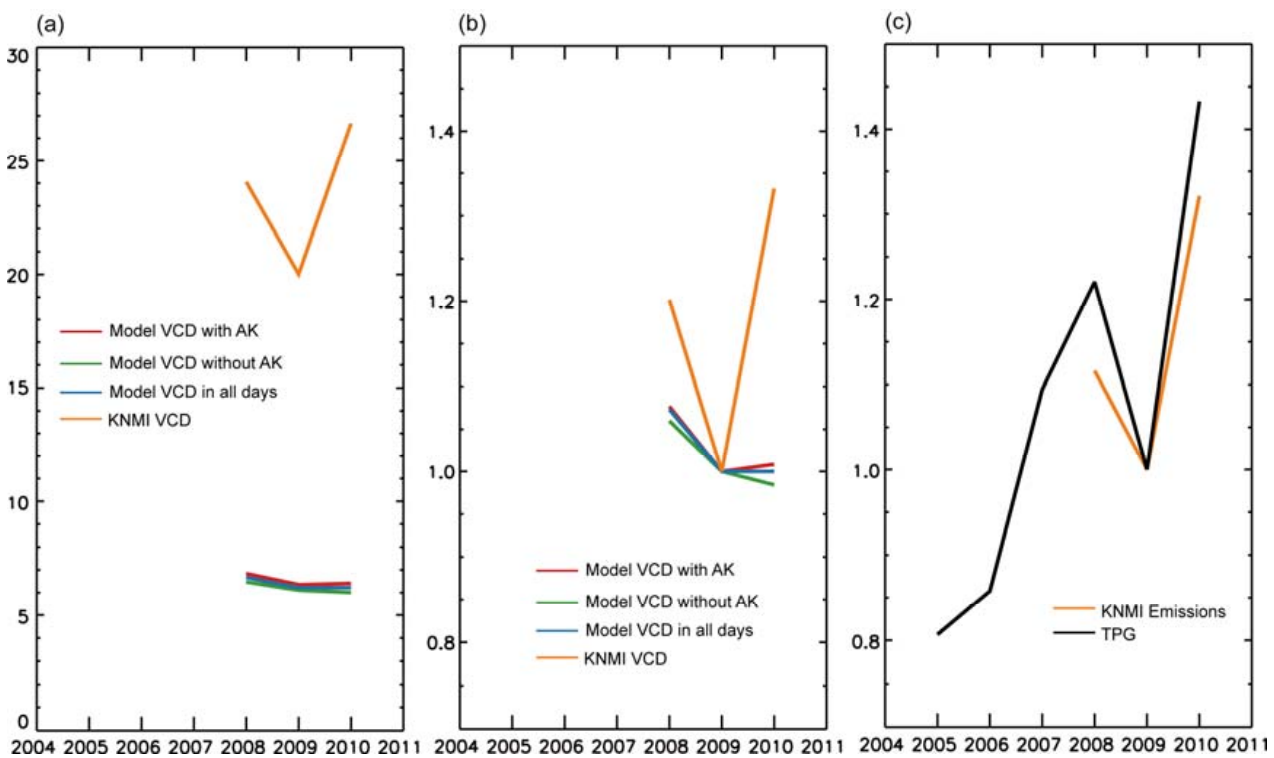

Fig. 8. Similar to Fig. 4 but for GOME-2. 

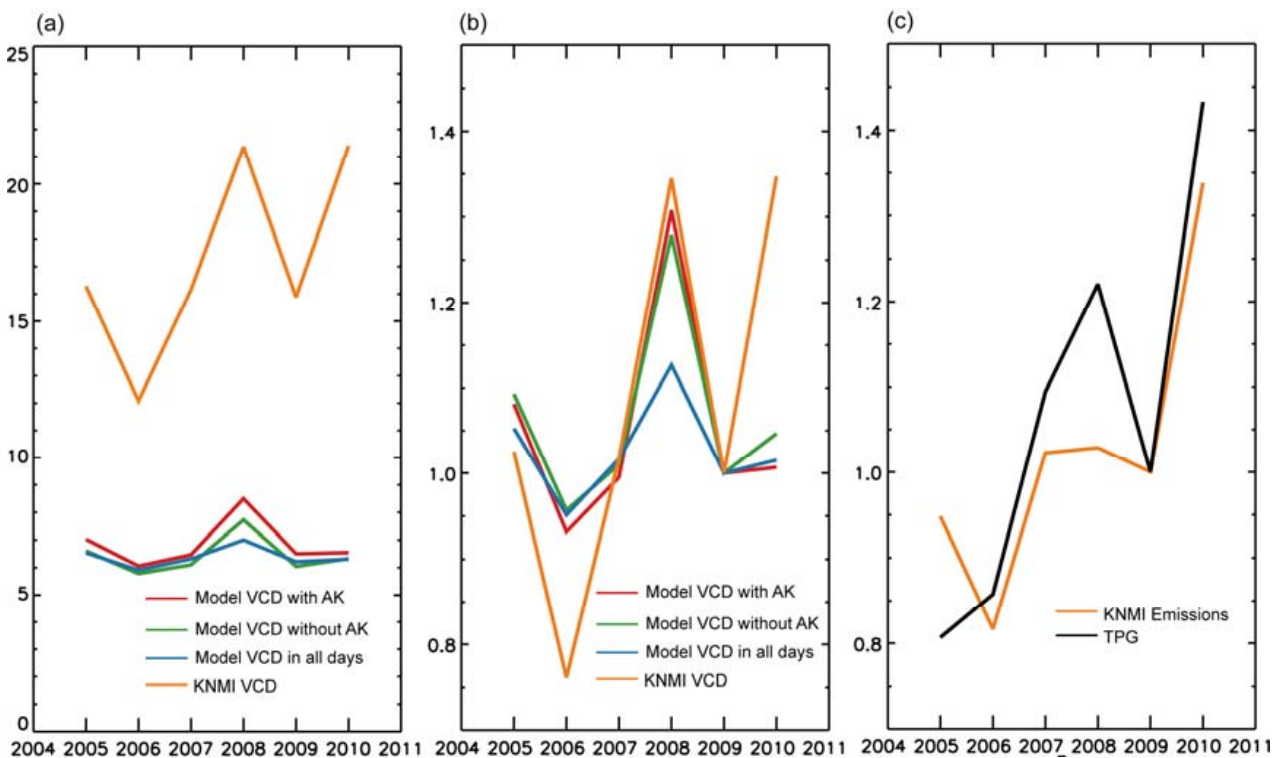

Fig. 9. Similar to Fig. 4 but for SCIAMACHY.

total emission reduction of $20 \%$ from January 2008 to January 2009 derived from OMI_KNMI, the negative effect of the downturn was calculated as $9 \%(11 \%)$ corresponding to an assumption of $12 \%(10 \%)$ for the negative effect of the CNY.

A third approach is taken by calculating the emissions using data of OMI_KNMI for days of January that were not influenced significantly by CNY. In January 2009, retrieved VCDs declined rapidly after 20 January (Fig. 10a). A minimum value is observed on 23 January, coincident with the passage of a cold front (with sharp increases in surface air pressure and decreases in surface air temperature) bringing cleaner air from the north. This cold event is captured by the model, including the timing of the local minimum in VCDs of $\mathrm{NO}_{2}$ (Fig. 10). However, modeled VCDs experience much weaker day-to-day variation after 20 January as compared to retrieved data. Therefore it is concluded that emissions of $\mathrm{NO}_{\mathrm{x}}$ were affected significantly by the CNY after 20 January 2009. The decline started earlier than the holiday partly because certain industries reduced production prior to the holiday (see the introduction).

In the third approach, the "monthly mean" VCD for January 2009 that would be independent of the CNY is approximated by the mean of VCDs during 1-20 January. This approximation is made both for OMI_KNMI and for model results in deriving the emissions. The calculation is unchanged for monthly mean VCDs in other months. Under this assumption, it is found that emissions of $\mathrm{NO}_{\mathrm{x}}$ decreased by about $11 \%$ from January 2008 to January 2009. This reflects the effect of the economic downturn alone, and is consistent with results from previous approaches assuming an impact of $10 \%$ from the CNY.
Overall, our best estimate suggests that the CNY and the economic downturn were responsible for reductions in emissions of $\mathrm{NO}_{\mathrm{x}}$ by $10 \%$ and $9-11 \%$, respectively. The effects of CNY and downturn derived here are subject to errors in the year-on-year change of retrieved VCDs $\left(R_{\mathrm{r}}\right)$, errors in the change of modeled VCDs $\left(R_{\mathrm{m}}\right)$, errors associated with the data coverage, and errors in the TPG-based estimate of the effect of CNY for January 2009. At the moment, it is difficult to estimate these four errors accurately due to the lack of sufficient information. However, their individual impacts are not expected to exceed $1.5 \%, 1.5 \%, 1 \%$, and $2.5 \%$, respectively, for each of the estimated effects of the downturn and CNY for January 2009. Assuming these errors are independent, their overall impact (calculated by summation in quadrature) is not expected to exceed $3.4 \%$. Furthermore, since the three approaches adopted in this study lead to similar results, it seems that these individual errors are compensated significantly by each other. Thus a value of $3.4 \%$ is most likely an upper limit for errors in the estimated effects of the downturn and CNY for January 2009.

\section{Conclusions and discussion}

Tropospheric VCDs of $\mathrm{NO}_{2}$ over the period October 2004 to February 2010 retrieved from SCIAMACHY, GOME-2 and OMI (both by KNMI and by NASA) are used to evaluate recent changes in emissions of $\mathrm{NO}_{\mathrm{X}}$ in industrialized and densely populated Northern East China and to identify the effect of the economic downturn during late 2008-late 2009. On a 12-month mean basis, retrieved VCDs of $\mathrm{NO}_{2}$ indicate a general increase from late 2004 to late 2008, a subsequent significant reduction during the downturn, and a resumption 
(a) $\mathrm{VCDs}$ of $\mathrm{NO}_{2}$

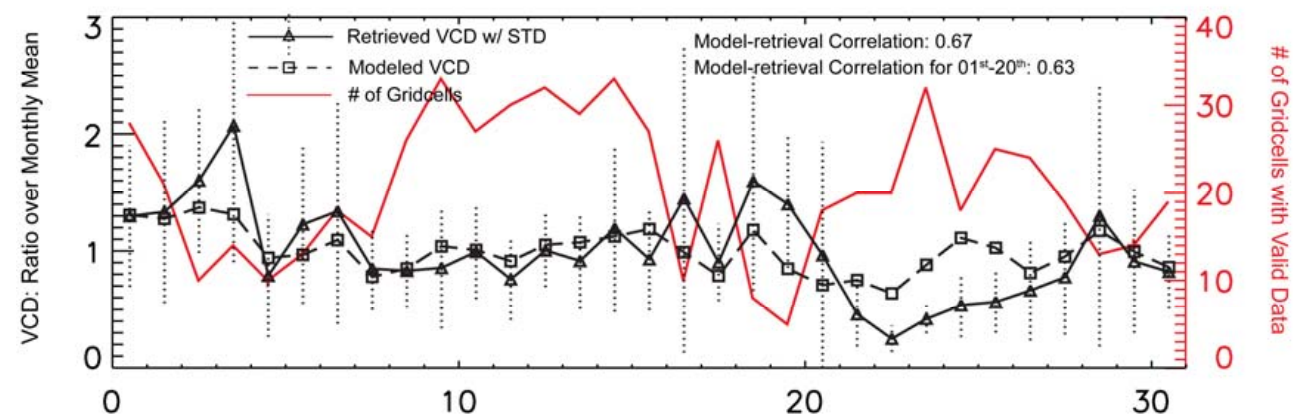

(b) Meteorological Parameters

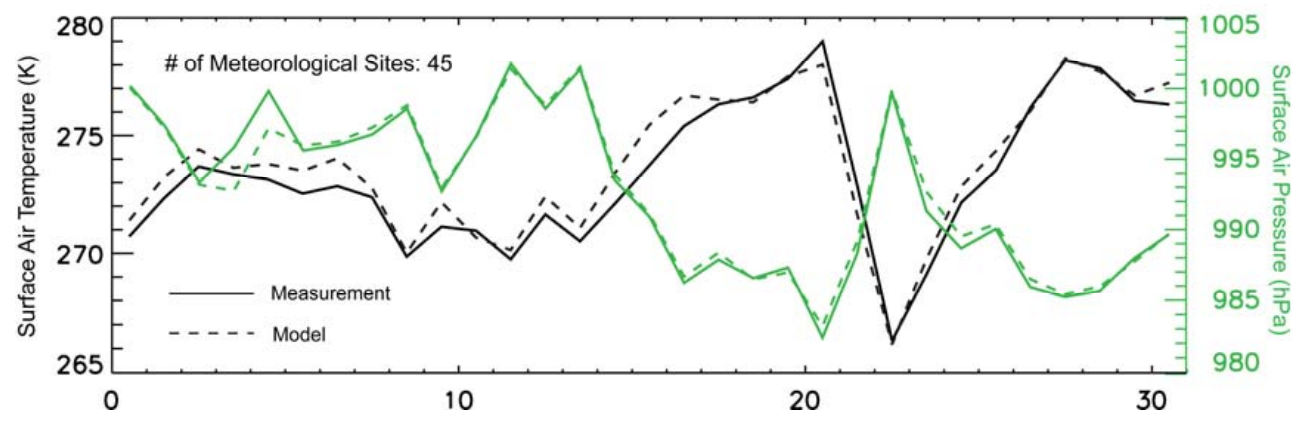

Fig. 10. Daily variations of regional mean $\mathrm{VCDs}$ of $\mathrm{NO}_{2}$ and meteorological parameters in January 2009. (a) Variations of retrieved (OMI_KNMI) and modeled VCDs of $\mathrm{NO}_{2}$ relative to regional means. Data in a given day are derived as the mean of the ratios of VCDs in gridcells with valid retrievals in that day over monthly mean VCDs in corresponding gridcells. Also shown is the number of gridcells out of the total of 36 over the region in each day that contain valid retrieval data. (b) Variations of measured and modeled daily average surface air temperature and surface air pressure. Meteorological measurements are taken from the global hourly dataset (DS3505) archived in the National Oceanic and Atmospheric Administration (NOAA) National Climatic Data Center (NCDC) (http://www7.ncdc.noaa.gov/CDO/cdo; see Lin et al. (2010a)). Daily average values for air temperature (air pressure) are calculated to be means over 3-hourly (6-hourly) data in correspondence to the temporal resolutions of individual model parameters.

of growth since mid 2009. The interannual variations are generally consistent with changes in thermal power generation used as a proxy for anthropogenic emissions of $\mathrm{NO}_{\mathrm{x}}$. Prior to the downturn, 12-month mean VCDs of $\mathrm{NO}_{2}$ increased by $27-33 \%$ (from October 2004-September 2005 to October 2007-September 2008) for SCIAMACHY and OMI (both by KNMI and by NASA), compared to the increase by $49 \%$ in thermal power generation.

More detailed analysis is conducted to quantify changes in emissions of $\mathrm{NO}_{\mathrm{x}}$ for January over 2005-2010, in which season the effect of the downturn is most evident. The global CTM GEOS-Chem is used to identify the effect of chemistry and meteorology on interannual variations of $\mathrm{VCDs}$ of $\mathrm{NO}_{2}$. Year-on-year changes in emissions of $\mathrm{NO}_{\mathrm{x}}$ for January derived from the OMI product produced by KNMI best capture changes in emissions inferred from the thermal power generation data. Estimated from the particular product, emissions decreased by $20 \%$ from January 2008 to January 2009, consistent with the decrease of $18 \%$ in thermal power generation.

The decline in emissions of $\mathrm{NO}_{\mathrm{x}}$ from January 2008 to January 2009 is found to be a consequence both of the eco- nomic downturn and of decrease in industrial activity during the Chinese New Year. The two factors are separated by three approaches based on data for thermal power generation and the OMI data from KNMI. It is concluded that the economic downturn led to a reduction of between 9 and $11 \%$ in emissions of $\mathrm{NO}_{\mathrm{x}}$, as compared to a reduction of $10 \%$ associated with the celebration of Chinese New Year. Errors in the estimate are most likely less than $3.4 \%$.

The present study suggests that satellite retrievals of tropospheric VCDs of $\mathrm{NO}_{2}$, while subject to significant uncertainties, provide meaningful information for evaluating relative changes in emissions of $\mathrm{NO}_{\mathrm{x}}$. This is consistent with previous studies (Richter et al., 2005; He et al., 2007; Stavrakou et al., 2008; van der A et al., 2008; Mijling et al., 2009; Yue et al., 2009; Zhang et al., 2009b). Furthermore, since emissions of $\mathrm{NO}_{\mathrm{x}}$ are tied closely to economic and industrial activities, retrievals of VCDs of $\mathrm{NO}_{2}$ may be used to provide an indirect proxy for changes in the economy - a valuable contribution particularly when official economic data are not readily available. 


\section{Appendix A}

\section{Comparisons of retrieved and modeled VCDs of $\mathrm{NO}_{2}$}

Errors exist in both retrieved and modeled VCDs of $\mathrm{NO}_{2}$, as discussed separately in Sects. 3 and 4. The overall effect of these errors can be estimated by comparing retrievals and model results for representative months.

For January 2006, model results are about $50 \%, 49 \%$ and $76 \%$ of the retrievals from SCIAMACHY, OMI_KNMI and OMI_NASA, respectively (Figs. 4a and 9a). Reducing KNMI retrievals by a factor of 1.4 (corresponding to an assumption that the retrievals are overestimated by $40 \%$; see Sect. 3 for a detailed analysis of retrieval errors) results in modelretrieval ratios of about $70 \%$ for both SCIAMACHY and OMO_KNMI. The remaining differences result from errors in retrievals and model simulations that have not been accounted for and inaccuracies in emission inputs of GEOSChem.

By January 2010, emissions of $\mathrm{NO}_{\mathrm{x}}$ have grown significantly from January 2006 as a consequence of rapid industrial development and inadequate emission controls (Zhao et al., 2009; Lei et al., 2010; Lin et al., 2010a), despite the temporary reductions associated with the economic downturn. Meanwhile, inputs of emissions were held unchanged in the CTM simulation. As a result, model VCDs depart further from satellite retrievals: they amount to only about $31 \%, 24 \%, 33 \%$ and $49 \%$ of values derived from SCIAMACHY, GOME-2, OMI_KNMI and OMI_NASA, respectively (Figs. 4a, 8a, and 9a). The model-retrieval ratios would be $43 \%, 34 \%, 46 \%$ relative to the three KNMI products, respectively, if a factor of 1.4 is applied to scale down the retrieval values. The model-retrieval difference is much larger for GOME-2 than for the other two KNMI products. This appears to suggest that errors in the GOME-2 product may be greater than $40 \%$, but the exact cause has to be revealed by future research.

\section{Appendix B}

\section{Effect of nonlinearity in nitrogen chemistry on derived emissions}

The abundance of $\mathrm{NO}_{2}$ in the troposphere is controlled by nonlinear photochemical processes affecting the lifetime of $\mathrm{NO}_{\mathrm{x}}$ and the partitioning between $\mathrm{NO}_{2}$ and NO. Here the sensitivity is evaluated for these two factors to changes in emissions of $\mathrm{NO}_{\mathrm{x}}, \mathrm{CO}$ and NMVOC under specified meteorological conditions.

Under given meteorological conditions, the lifetime of $\mathrm{NO}_{\mathrm{x}}$ and the $\mathrm{NO}_{2}-\mathrm{NO}$ partitioning may be affected by changes in emissions of $\mathrm{NO}_{\mathrm{x}}$ through the nonlinear photochemistry. Stavrakou et al. (2008) found that an increase of
70-100\% in emissions of $\mathrm{NO}_{\mathrm{x}}$ (from 1997 to 2006) results in an increase of $10 \%$ in the lifetime of $\mathrm{NO}_{\mathrm{x}}$ in winter over Northern East China due to reduced concentration of $\mathrm{OH}$. This effect, however, is partly offset by a reduced $\mathrm{NO}_{2}: \mathrm{NO}$ ratio (Martin et al., 2006). As a result, Martin et al. (2006) found that $\mathrm{VCDs}$ of $\mathrm{NO}_{2}$ are highly proportional to emissions of $\mathrm{NO}_{\mathrm{x}}$ for a wide range of emissions both in summer and in winter.

In this study, the effect of increasing emissions of $\mathrm{NO}_{\mathrm{x}}$ on VCDs of $\mathrm{NO}_{2}$ is evaluated further by feeding into the model simulation for January 2010 the $47 \%$ increase in anthropogenic emissions of $\mathrm{NO}_{\mathrm{x}}$ from January 2006 to January 2010 derived from OMI_KNMI (see Sect. 6.2.1). A sensitivity simulation for January 2010 driven by the enhanced emissions resulted in an increase of about $47 \%$ in monthly mean VCDs of $\mathrm{NO}_{2}$. This suggests that changes in emissions of $\mathrm{NO}_{\mathrm{x}}$ derived in this study are affected insignificantly by the nonlinear photochemistry, consistent with the findings of Martin et al. (2006).

Changes in emissions of $\mathrm{CO}$ and NMVOC since 2005 may affect VCDs of $\mathrm{NO}_{2}$ by affecting the abundances of ozone, $\mathrm{OH}$, and other radicals. This effect was found by Lin et al. (2010b) to be insignificant for July 2008 employing a sensitivity test increasing emissions of $\mathrm{CO}$ and NMVOC by $50 \%$. In winter, the photochemical activity in the troposphere is much lower than that in summer. Therefore the effect of changing CO and NMVOC since 2005 is not expected to be important in deriving emissions of $\mathrm{NO}_{\mathrm{x}}$ in winter.

\section{Appendix C}

\section{Effects of non-emission factors on (OMI_KNMI associated) modeled year-on-year changes in VCDs of $\mathrm{NO}_{2}$}

A variety of factors other than emissions may affect the abundance of $\mathrm{NO}_{2}$ in the troposphere observed by OMI. They are discussed here by employing results of GEOS-Chem simulations sampled at the overpass time of OMI.

Year-on-year changes in chemical and meteorological conditions have an influence on VCDs of $\mathrm{NO}_{2}$, as simulated by the CTM with constant emissions of $\mathrm{NO}_{\mathrm{x}}$ (and sampled from all days) (Fig. 4a, b; blue lines). The model VCD averaged over Northern East China varied by about $7 \%$ year to year, with a minimum in January 2006 and a maximum in January 2008. The changes were contributed partly by variations in the planetary boundary layer height $(\mathrm{PBLH})$. As shown in Fig. 6, the PBLH reached a minimum in January 2006 and a maximum in January 2008, with a difference of $\sim 30 \%$, affecting the vertical distributions of a variety of species important for the nitrogen chemistry. A sensitivity simulation increasing the PBLH by $30 \%$ for January 2006 resulted in an increase of about $4 \%$ in modeled VCDs of $\mathrm{NO}_{2}$. Meanwhile, surface air temperature in January 2008 was about $2{ }^{\circ} \mathrm{C}$ lower 
than January 2006, increasing the reaction rate of $\mathrm{OH}+\mathrm{NO}_{2}$ (a termolecular reaction) and decreasing the thermal decomposition of $\mathrm{N}_{2} \mathrm{O}_{5}$. The temperature difference thus tends to result in a lifetime of $\mathrm{NO}_{\mathrm{x}}$ in January 2008 shorter than that in January 2006, compensating for the effect of varying PBLH. Wind speed and precipitation are not found to be significant factors for the differences in modeled VCD of $\mathrm{NO}_{2}$ between January 2006 and January 2008 (not shown). Other non-emission factors affecting the abundance of $\mathrm{NO}_{2}$ include cyclone passages, clouds, aerosols, and stratospheric ozone (affecting the radiation into the troposphere). Further research is required for a more systematic analysis specifying the impacts of individual factors on VCDs of $\mathrm{NO}_{2}$.

Satellite retrievals are not available for all locations for all days due to the existence of clouds, ice, snow and instrument limitations (e.g., row anomalies in OMI measurements) (Fig. 2). The effect of data availability can be evaluated by comparing simulated VCDs based on model results for all days with those sampled from days with valid satellite data (Fig. 4a, b; green lines versus blue lines). The reduced number of days for sampling results in a larger (smaller) difference in January mean VCD between 2006 (2008) and 2009.

Furthermore, satellite retrievals are subject to errors in the a priori vertical profiles of $\mathrm{NO}_{2}$. The effect on retrievalmodel comparisons for $\mathrm{VCDs}$ of $\mathrm{NO}_{2}$ can be eliminated by applying the AK to model results. Year-on-year changes in January mean VCD (as simulated by the CTM) differ significantly between model results with and without applying the AK, particularly for 2007 and 2008 (Figs. 4a,b; green lines versus red lines). This indicates that the a priori vertical profile of $\mathrm{NO}_{2}$ differs from the profile simulated by GEOSChem, and that the AK should be used (as in this study) for a proper model-retrieval comparison.

Acknowledgements. This research is supported by the National Natural Science Foundation of China, grant 41005078, and the National Science Foundation, grant ATM-1019134. We thank Chris Nielsen for useful discussions. We acknowledge the free use of tropospheric $\mathrm{NO}_{2}$ column data from www.temis.nl and http://mirador.gsfc.nasa.gov.

Edited by: M. Schulz

\section{References}

Acarreta, J. R., De Haan, J. F., and Stammes, P.: Cloud pressure retrieval using the $\mathrm{O}_{2}^{-}-\mathrm{O}_{2}^{-}$absorption band at $477 \mathrm{~nm}$, J. Geophys. Res., 109, D05204, doi:10.1029/2003jd003915, 2004.

Bertram, T. H., Thornton, J. A., Riedel, T. P., Middlebrook, A. M., Bahreini, R., Bates, T. S., Quinn, P. K., and Coffman, D. J.: Direct observations of $\mathrm{N}_{2} \mathrm{O}_{5}$ reactivity on ambient aerosol particles, Geophys. Res. Lett., 36, L19803, doi:10.1029/2009g1040248, 2009.

Boersma, K. F., Eskes, H. J., and Brinksma, E. J.: Error analysis for tropospheric $\mathrm{NO}_{2}$ retrieval from space, J. Geophys. Res., 109, D04311, doi:10.1029/2003JD003962, 2004.
Boersma, K. F., Eskes, H. J., Veefkind, J. P., Brinksma, E. J., van der A, R. J., Sneep, M., van den Oord, G. H. J., Levelt, P. F., Stammes, P., Gleason, J. F., and Bucsela, E. J.: Near-real time retrieval of tropospheric $\mathrm{NO}_{2}$ from OMI, Atmos. Chem. Phys., 7, 2103-2118, doi:10.5194/acp-7-2103-2007, 2007.

Boersma, K. F., Jacob, D. J., Bucsela, E. J., Perring, A. E., Dirksen, R., van der A, R. J., Yantosca, R. M., Park, R. J., Wenig, M. O., Bertram, T. H., and Cohen, R. C.: Validation of OMI tropospheric $\mathrm{NO}_{2}$ observations during INTEX-B and application to constrain $\mathrm{NO}_{\mathrm{x}}$ emissions over the eastern United States and Mexico, Atmos. Environ., 42, 4480-4497, doi:10.1016/j.atmosenv.2008.02.004, 2008.

Boersma, K. F., Jacob, D. J., Trainic, M., Rudich, Y., DeSmedt, I., Dirksen, R., and Eskes, H. J.: Validation of urban $\mathrm{NO}_{2}$ concentrations and their diurnal and seasonal variations observed from the SCIAMACHY and OMI sensors using in situ surface measurements in Israeli cities, Atmos. Chem. Phys., 9, 3867-3879, doi:10.5194/acp-9-3867-2009, 2009.

Boersma, K. F., Eskes, H. J., Dirksen, R. J., van der A, R. J., Veefkind, J. P., Stammes, P., Huijnen, V., Kleipool, Q. L., Sneep, M., Claas, J., Leitão, J., Richter, A., Zhou, Y., and Brunner, D.: An improved tropospheric $\mathrm{NO}_{2}$ column retrieval algorithm for the Ozone Monitoring Instrument, Atmos. Meas. Tech. Discuss., 4, 2329-2388, doi:10.5194/amtd-4-2329-2011, 2011.

Brown, S. S., Dube, W. P., Fuchs, H., Ryerson, T. B., Wollny, A. G., Brock, C. A., Bahreini, R., Middlebrook, A. M., Neuman, J. A., Atlas, E., Roberts, J. M., Osthoff, H. D., Trainer, M., Fehsenfeld, F. C., and Ravishankara, A. R.: Reactive uptake coefficients for $\mathrm{N}_{2} \mathrm{O}_{5}$ determined from aircraft measurements during the Second Texas Air Quality Study: Comparison to current model parameterizations, J. Geophys. Res., 114, D00F10, doi:10.1029/2008jd011679, 2009.

Bucsela, E. J., Perring, A. E., Cohen, R. C., Boersma, K. F., Celarier, E. A., Gleason, J. F., Wenig, M. O., Bertram, T. H., Wooldridge, P. J., Dirksen, R., and Veefkind, J. P.: Comparison of tropospheric $\mathrm{NO}_{2}$ from in situ aircraft measurements with near-real-time and standard product data from OMI, J. Geophys. Res., 113, D16S31, doi:10.1029/2007jd008838, 2008.

China Statistical Yearbook 2009, China Statistics Press, Beijing, China, 2009

Dirksen, R. J., Boersma, K. F., Eskes, H. J., Ionov, D. V., Bucsela, E. J., Levelt, P. F., and Kelder, H. M.: Evaluation of stratospheric $\mathrm{NO}_{2}$ retrieved from the Ozone Monitoring Instrument: Intercomparison, diurnal cycle, and trending, J. Geophys. Res., 116, D08305, doi:10.1029/2010jd014943, 2011.

Evans, M. J. and Jacob, D. J.: Impact of new laboratory studies of N2O5 hydrolysis on global model budgets of tropospheric nitrogen oxides, ozone, and OH, Geophys. Res. Lett., 32, L09813, doi:10.1029/2005g1022469, 2005.

Hains, J. C., Boersma, K. F., Kroon, M., Dirksen, R. J., Cohen, R. C., Perring, A. E., Bucsela, E., Volten, H., Swart, D. P. J., Richter, A., Wittrock, F., Schoenhardt, A., Wagner, T., Ibrahim, O. W., van Roozendael, M., Pinardi, G., Gleason, J. F., Veefkind, J. P., and Levelt, P.: Testing and improving OMI DOMINO tropospheric $\mathrm{NO}_{2}$ using observations from the DANDELIONS and INTEX-B validation campaigns, J. Geophys. Res., 115, D05301, doi:10.1029/2009jd012399, 2010.

He, Y., Uno, I., Wang, Z., Ohara, T., Sugirnoto, N., Shimizu, A., Richter, A., and Burrows, J. P.: Variations of the in- 
creasing trend of tropospheric $\mathrm{NO}_{2}$ over central east China during the past decade, Atmos. Environ., 41, 4865-4876, doi:10.1016/j.atmosenv.2007.02.009, 2007.

Herman, J. R. and Celarier, E. A.: Earth surface reflectivity climatology at 340-380 nm from TOMS data, J. Geophys. Res., 102, 28003-28011, 1997.

Holtslag, A. and Boville, B.: Local versus nonlocal boundary-layer diffusion in a global climate model, J. Climate, 6, 1825-1842, 1993.

Jaeglé, L., Steinberger, L., Martin, R. V., and Chance, K.: Global partitioning of $\mathrm{NO}_{\mathrm{x}}$ sources using satellite observations: Relative roles of fossil fuel combustion, biomass burning and soil emissions, Faraday Discuss., 130, 407-423, doi:10.1039/b502128f, 2005.

Koelemeijer, R. B. A., Stammes, P., Hovenier, J. W., and de Haan, J. F.: A fast method for retrieval of cloud parameters using oxygen A band measurements from the Global Ozone Monitoring Experiment, J. Geophys. Res., 106, 3475-3490, 2001.

Koelemeijer, R. B. A., de Haan, J. F., and Stammes, P.: A database of spectral surface reflectivity in the range 335-772 nm derived from 5.5 years of GOME observations, J. Geophys. Res., 108, 4070, doi:10.1029/2002jd002429, 2003.

Lamsal, L. N., Martin, R. V., van Donkelaar, A., Celarier, E. A., Bucsela, E. J., Boersma, K. F., Dirksen, R., Luo, C., and Wang, Y.: Indirect validation of tropospheric nitrogen dioxide retrieved from the OMI satellite instrument: Insight into the seasonal variation of nitrogen oxides at northern midlatitudes, J. Geophys. Res., 115, D05302, doi:10.1029/2009jd013351, 2010.

Lei, Y., Zhang, Q., Nielsen, C. P., and He, K.: An inventory of primary air pollutants and $\mathrm{CO}_{2}$ emissions from cement production in China, 1990-2020, Atmos. Environ., 45, 147-154, 2010.

Lin, J. T. and McElroy, M. B.: Impacts of boundary layer mixing on pollutant vertical profiles in the lower troposphere: Implications to satellite remote sensing, Atmos. Environ., 44, 17261739, doi:10.1016/j.atmosenv.2010.02.009, 2010.

Lin, J., Nielsen, C., Zhao, Y., Lei, Y., Liu, Y., and McElroy, M. B.: Recent changes in particulate air pollution over China observed from space and the ground, Environ. Sci. Technol., 44, 77717776, doi:10.1021/es101094t, 2010a.

Lin, J. T., McElroy, M. B., and Boersma, K. F.: Constraint of anthropogenic $\mathrm{NO}_{\mathrm{x}}$ emissions in China from different sectors: a new methodology using multiple satellite retrievals, Atmos. Chem. Phys., 10, 63-78, doi:10.5194/acp-10-63-2010, 2010b.

Martin, R. V., Jacob, D. J., Chance, K., Kurosu, T. P., Palmer, P. I., and Evans, M. J.: Global inventory of nitrogen oxide emissions constrained by space-based observations of $\mathrm{NO}_{2}$ columns, J. Geophys. Res., 108, 4573, doi:10.1029/2003JD003453, 2003.

Martin, R. V., Sioris, C. E., Chance, K., Ryerson, T. B., Bertram, T. H., Wooldridge, P. J., Cohen, R. C., J. Andy Neuman, Swanson, A., and Flocke, F. M.: Evaluation of space-based constraints on global nitrogen oxide emissions with regional aircraft measurements over and downwind of eastern North America, J. Geophys. Res., 111, D15308, doi:10.1029/2005JD006680, 2006.

McElroy, M. B., Lu, X., Nielsen, C. P., and Wang, Y. X.: Potential for Wind-Generated Electricity in China, Science, 325, 13781380, doi:10.1126/science.1175706, 2009.

Mijling, B., van der A, R. J., Boersma, K. F., Van Roozendael, M., De Smedt, I., and Kelder, H. M.: Reductions of $\mathrm{NO}_{2}$ detected from space during the 2008 Beijing Olympic Games, Geophys.
Res. Lett., 36, D13801, doi:10.1029/2009g1038943, 2009.

Richter, A., Burrows, J. P., Nu“ $ß$, H., Granier, C., and Niemeier, U.: Increase in tropospheric nitrogen dioxide over China observed from space, Nature, 437, 129-132, doi:10.1038/nature04092, 2005.

Seinfeld, J. H., and Pandis, S. N.: Atmospheric Chemistry and Physics: From Air Pollution to Climate Change, Second ed., John Wiley \& Sons, Inc., Hoboken, New Jersey, USA, 2006.

Stavrakou, T., Muller, J. F., Boersma, K. F., De Smedt, I., and van der A, R. J.: Assessing the distribution and growth rates of $\mathrm{NO}_{\mathrm{x}}$ emission sources by inverting a 10-year record of $\mathrm{NO}_{2}$ satellite columns, Geophys. Res. Lett., 35, L10801, doi:10.1029/2008g1033521, 2008.

Streets, D. G., Bond, T. C., Carmichael, G. R., Fernandes, S. D., Fu, Q., He, D., Klimont, Z., Nelson, S. M., Tsai, N. Y., Wang, M. Q., Woo, J. H., and Yarber, K. F.: An inventory of gaseous and primary aerosol emissions in Asia in the year 2000, J. Geophys. Res., 108, 8809, doi:10.1029/2002jd003093, 2003.

van $\operatorname{der}$ A, R. J., Peters, D., Eskes, H., Boersma, K. F., Van Roozendael, M., De Smedt, I., and Kelder, H. M.: Detection of the trend and seasonal variation in tropospheric $\mathrm{NO}_{2}$ over China, J. Geophys. Res., 111, D12317, doi:10.1029/2005jd006594, 2006.

van $\operatorname{der}$ A, R. J., Eskes, H. J., Boersma, K. F., Noije, T. P. C. v., Roozendael, M. V., DeSmedt, I., Peters, D. H. M. U., and Meijer, E. W.: Trends, seasonal variability and dominant $\mathrm{NO}_{\mathrm{x}}$ source derived from a ten year record of $\mathrm{NO}_{2}$ measured from space, $\mathrm{J}$. Geophys. Res., 113, D04302, doi:10.1029/2007JD009021, 2008.

Wang, P., Stammes, P., van der A, R., Pinardi, G., and van Roozendael, M.: FRESCO+: an improved $\mathrm{O}_{2}$ A-band cloud retrieval algorithm for tropospheric trace gas retrievals, Atmos. Chem. Phys., 8, 6565-6576, doi:10.5194/acp-8-6565-2008, 2008.

Wang, Y., McElroy, M. B., Martin, R. V., Streets, D. G., Zhang, Q., and Fu, T.-M.: Seasonal variability of $\mathrm{NO}_{\mathrm{x}}$ emissions over east China constrained by satellite observations: Implications for combustion and microbial sources, J. Geophys. Res., 112, D06301, doi:10.1029/2006JD007538, 2007.

Yue, J., Lin, Y., Deng, Z., and Zhao, C.: Seasonal Variations of Tropospheric $\mathrm{NO}_{2}$ over Megalopolis in Eastern China Using Satellite Remote-Sensing Data and Chemistry-Transport Model (in Chinese), Proceedings of Peking University, 45, 2009.

Zhang, Q., Streets, D. G., He, K., Wang, Y., Richter, A., Burrows, J. P., Uno, I., Jang, C. J., Chen, D., Yao, Z., and Lei, Y.: $\mathrm{NO}_{\mathrm{X}}$ emission trends for China, 1995-2004: The view from the ground and the view from space, J. Geophys. Res., 112, D22306, doi:10.1029/2007JD008684, 2007.

Zhang, Q., Streets, D. G., Carmichael, G. R., He, K. B., Huo, H., Kannari, A., Klimont, Z., Park, I. S., Reddy, S., Fu, J. S., Chen, D., Duan, L., Lei, Y., Wang, L. T., and Yao, Z. L.: Asian emissions in 2006 for the NASA INTEX-B mission, Atmos. Chem. Phys., 9, 5131-5153, doi:10.5194/acp-9-5131-2009, 2009a.

Zhang, Q., Streets, D. G., and He, K. B.: Satellite observations of recent power plant construction in Inner Mongolia, China, Geophys. Res. Lett., 36, L15809, doi:10.1029/2009g1038984, 2009b.

Zhao, Y., Duan, L., Xing, J., Larssen, T., Nielsen, C. P., and Hao, J. M.: Soil Acidification in China: Is Controlling SO2 Emissions Enough?, Environ. Sci. Technol., 43, 8021-8026, doi:10.1021/es901430n, 2009.

Zhao, Y., Wang, S., Nielsen, C. P., Li, X., and Hao, J.: Establishment of a database of emission factors for atmospheric pollu- 
tants from Chinese coal-fired power plants, Atmos. Environ., 44, 1515-1523, doi:10.1016/j.atmosenv.2010.01.017, 2010.

Zhou, Y., Brunner, D., Boersma, K. F., Dirksen, R., and Wang, P.: An improved tropospheric $\mathrm{NO}_{2}$ retrieval for OMI observations in the vicinity of mountainous terrain, Atmos. Meas. Tech., 2, 401-416, doi:10.5194/amt-2-401-2009, 2009. 